\title{
Potential PET Ligands for Imaging of Cerebral VPAC and PAC Receptors: Are Non-Peptide Small Molecules Superior to Peptide Compounds?
}

\author{
Margit Pissarek \\ INM-5, Nuclear Chemistry, Institute of Neurosciences and Medicine, Research Centre Jülich, \\ Jülich, Germany \\ Email:m.pissarek@fz-juelich.de
}

Received 15 August 2015; accepted 13 November 2015; published 17 November 2015

Copyright (C) 2015 by author and Scientific Research Publishing Inc.

This work is licensed under the Creative Commons Attribution International License (CC BY). http://creativecommons.org/licenses/by/4.0/

(c) (i) Open Access

\section{Abstract}

Pituitary adenylate cyclase activating polypeptide (PACAP) and vasoactive intestinal peptide (VIP) have been known for decades to mediate neuroendocrine and vasodilative actions via G-proteincoupled receptors of Class $B$. These are targets of imaging probes for positron emission tomography (PET) or single photon emission tomography (SPECT) in tumor diagnostics and tumor grading. However, they play only a subordinate role in the development of tracers for brain imaging. Difficulties in development of non-peptide ligands typical for cerebral receptors of PACAP and VIP are shared by all members of Class B receptor family. Essential landmarks have been confirmed for understanding of structural details of Class $B$ receptor molecular signalling during the last five years. High relevance in the explanation of problems in ligand development for these receptors is admitted to the large $\mathrm{N}$-terminal ectodomain markedly different from Class $\mathrm{A}$ receptor binding sites and poorly suitable as orthosteric binding sites for the most small-molecule compounds. The present study is focused on the recently available receptor ligands for PAC1, VPAC1 and VPAC2 receptors as well as potential small-molecule lead structures suitable for use in PET or SPECT. Recently, biaryl, cyanothiophene and pentanamide structures with affinities in nM-range have been proposed as non-peptide ligands at VPAC1 and VPAC2 receptors. However, most of these ligands have been classified as non-competitive related to the orthosteric binding site of endogenous peptide ligands of VPAC receptors. For PAC1 receptors have been identified hydrazide compounds for which an inhibitory and potentially competitive mechanism of receptor binding has been postulated based on molecular docking studies. 


\section{Keywords}

\section{Class B Receptors, Vasoactive Intestinal Peptide, Pituitary Adenylate Cyclase Activating Polypeptide, Non-Peptide Ligands, PET, SPECT}

\section{Introduction}

Vasoactive intestinal peptide (VIP) [1] [2] and pituitary adenylate cyclase activating peptide (PACAP) [3] [4] activate three types of G-protein-coupled receptors (GPCR) which belong to the Class B receptor family (secretin/glucagon/VIP receptors) and have been intensively investigated [5]-[7] for their structure-activity relationships (SAR) and localization in peripheral tissues and CNS [8]-[11]. These PAC1, VPAC1 and VPAC2 receptors can be found in special regions of brain and spinal cord in densities potentially suitable for in vivo imaging with high affinity radiotracer ligands [9]. High attention is paid to these receptors in the areas of pulmology, immunology, diabetology, ophtalmology as well as traumatology predominantly for the development of effective therapeutics [12]-[19]. However, such receptors are rather outsiders regarding successes in brain imaging with positron emission tomography (PET) and single photon emission tomography (SPECT). Brain disorders providing potential therapeutic applications for ligands of these receptors include chronic inflammatory diseases, neurodegenerative disorders, schizophrenia and stress reactions [14] [15] [20] [21]. The diagnostic possibilities of small-molecule PET-receptor ligands have been not finally assessed up to now. Modern crystallographic and molecular biological methods allowed the discovery of functional variations of these receptors to play a role in the switch between distinct regulatory pathways and permit insights in the manifold regulatory possibilities of these structures [10] [22]-[25] as well as of species differences [26]. However, only few non-peptide small-molecule ligands are available for receptors of VIP and PACAP hitherto. But other Class B GPCR receptors, characterized by similar conformations of the $\mathrm{N}$-terminal ectodomain ( $\mathrm{N}$-ted), have been a target of in vivo neuroimaging experiments for detection of disease-related alterations for many years. Some success has been reported in the development of positron-emitter-labelled non-peptide compounds. Thus, in vivo trials were reported for imaging of ligands of corticotrophin releasing factor receptors (CRFR) and of calcitonin gene-related peptide receptors (CGRPR) in monkeys in 2007 [27]-[29] and 2013 [30], respectively.

Structural differences between the N-teds recently described for Class A and Class B GPCRs as binding sites for endogenous peptides have been confirmed also by crystallographic studies [31]-[37]. Additionally, receptor activity modulating proteins (RAMP) have been found for almost all Class B receptors up to now (cf. Table 1).

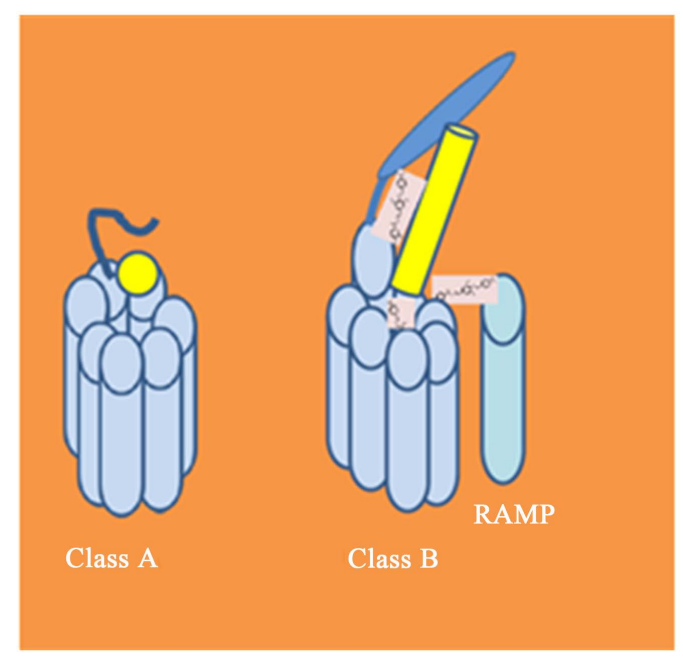

Figure 1. Simplified schematic comparison of the N-teds of Class A and Class B receptors. Three potential binding sites of small molecule ligands (mauve) at Class B receptors and RAMP are indicated. Modified according to [48] [84] [132] [133] (yellow: ligand of the receptor, dark blue: $\mathrm{N}$-terminal ectodomain of the receptor; light blue: 7 TM domain. 
The tasks of these accessory transmembrane proteins have been assigned to the field of the support of the receptor protein in trafficking via the endoplasmatic reticulum to the cellular membrane [35] [41] [42]. Furthermore, a potential role of the RAMP ectodomain in the binding of drugs and imaging probes has been suggested [43] (cf. Figure 1; $c f$. Figure 2).

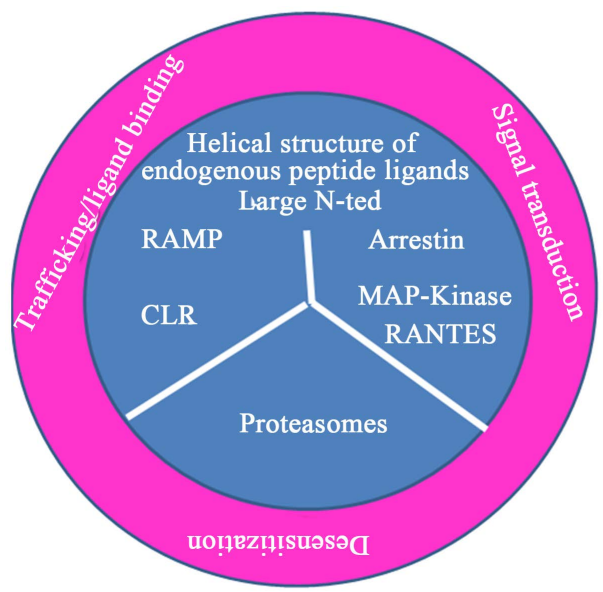

Figure 2. Some recently discussed functional determinants of Class B receptor signalling. Large N-ted (N-terminal extracellular domain): is the critical structure discussed in the "two domain model" [84] (ligand binding to the N-ted domain initiates a conformation which allows access of the ligand to transmembrane or juxtamembrane orthosteric binding site) and in the "hidden agonist model" (binding of a ligand opens the real binding site for an endogenous agonist) [84] [86]. Helix structure of endogenous peptide ligands: relatively large endoligands allow positioning at the $\mathrm{N}$-ted which cannot easily mimicked by small molecules. RAMP: contribute to trafficking of receptors and their progenitor proteins to the cellular membrane and can be involved in ligand binding at the membrane receptor. CLR: (calcitonin receptor-like receptor): GPCR forming by heterodimerization with different RAMPs several receptor subfamilies. Arrestins: regulatory key signalling proteins probably similar important like $G$ proteins and determining for bias to long- or short-term actions of the receptors. RANTES: microglia mediated mechanism of neuroprotection. Proteasomes: key units of protein catabolism following receptor internalization. Limited capacity might facilitate disturbances of protein folding or protein misfolding.

Table 1. Some Class B receptors and interactions with RAMP subtypes reported to date.

\begin{tabular}{ccc}
\hline Receptor & Interacts with & Reference \\
\hline CFR1 & RAMP2 & {$[38]$} \\
CGRP & RAMP1 & {$[39]$} \\
CT & RAMP1-3 & {$[39]$} \\
AM1 & RAMP2 & {$[36]$} \\
AM2 & RAMP3 & {$[36]$} \\
AMY1-3 & RAMP1-3 & {$[36]$} \\
VPAC1 & RAMP1-3 & {$[30]$} \\
VPAC2 & RAMP1-3 & {$[39]$} \\
PTH1 & RAMP2 & {$[36]$} \\
PTH2 & RAMP3 & {$[39]$} \\
Secretin & RAMP2 & {$[40]$} \\
Glucagon & RAMP3 & {$[38]$} \\
GLP-1 & & {$[38]$} \\
GLP-2 & & \\
\hline
\end{tabular}


Labelling of ligands at VIP and PACAP specific receptors with PET or SPECT isotopes has been confined predominantly to peptide compounds which are applied or developed for localization, grading and therapy of cancers [44] [45]. Ligands of VPAC1 and VPAC2 receptors have been employed predominantly for the identification of adenocarcinoma of breast, tumors of prostate, liver, stomach as well as of small cell lung cancer [45].

Non-peptide compounds up to now achieved affinities rather in submicromolar than in subnanomolar range. Reports on in vivo imaging experiments are not available. First small molecules of this kind were identified as ligands of the PAC1 receptor seven years ago [46]. An antagonist of the VPAC2 receptor was reported two years later [47]. The present study regards the first lead structures for its pharmacokinetic and binding properties, some further progress in development of VPAC and PAC receptor tracers as well as some of its limitations.

\section{VPAC1, VPAC2, PAC1 Receptors and Their Peptide Ligands}

\subsection{Endogenous Ligands PACAP and VIP}

The endogenous ligands at these receptors, PACAP (27 or 38 a.a.r.) and VIP (28 a.a.r.), share some common features with other peptide ligands of the secretin-glucagon family of GPCRs.

The endogenous ligands of Class B receptors have amino acid sequences in the range between 27 and 44 a.a.r. in mammalian. They are synthetized by endocrine cells, neurons or immune cells. They form $\alpha$ helices and contain an NCap structure in the N-terminal part [18] [48] [49]. PACAP has been recognized as a compound acting as hormone, neurohormone, neurotransmitter and neurotrophic factor [50]. It is found in the brain, cardiovascular system, thyroid, pituitary, adrenal gland and placenta [10] [13] [51]-[53]. Both, PACAP and VIP, are regarded as master switches of circadian rhythm [54] [55]. For VIP its role as regulator of growth of whole fetus and of the embryonic brain has been classified as another important long-term effect, while short- term activities with involvement of VIP include exocrine secretion, hormone release, muscle relaxation and metabolic actions [18]. Furthermore, VIP is involved in neuroprotective, antiinflammatory and immunmodulatory effects and influences cell proliferation in cancer cells [10]. The level of PACAP38 in adult brain of mice has been found in the range of $120 \mathrm{fmol} / \mathrm{mg}$ protein and the level of VIP at $500 \mathrm{fmol} / \mathrm{mg}$ protein [56]. The levels of both peptides are changing from embryonic to adult age in murine brain [57]. PACAP was found at $24 \mathrm{fmol} / \mathrm{mg}$ protein at postnatal day 1 and VIP at $9.4 \mathrm{fmol} / \mathrm{mg}$ protein [56] at the same stage of development. PACAP achieves levels of the adult brain some days earlier than VIP. It binds to PAC1 with 1000 fold higher affinity than VIP but shows similar affinities to VPAC receptors like VIP [58].

The selectivity between the three relevant receptors has been investigated in models of SAR at first for VIP [59] [60], and subsequently also for PACAP [25] [58]. The first concise pharmacophore model of VIP at VPAC1 and VPAC2 receptors with systematic description of functional relevance of all a.a.r.s was provided by Nicole et al. (2000) [59]. A characterization of PACAP at the PAC1 receptor was later presented by Sun et al. [58] and Kumar et al. [23]. Nicole et al. identified T11 and N28 by alanine scanning, energetic optimization as well as investigations of pharmacodynamics as pivotal structures for the binding of VIP to VPAC receptors. For PACAP38, it has been observed that the removal of the first five amino acids can transform the polypeptide from an agonist at the PAC1 receptor into an antagonist without alteration of the binding affinity [58] [61].

Regarding the functional roles of the peptides, for PACAP essential part of attention has been paid to its contribution to stress response [24], whereas the main fields for VIP investigation are inflammatory diseases [62] and its cytokine-like role. However, for both peptides have been shown influences of knock-out on behavioral functions and on early development in mammals too [24] [35] [63], e.g. in PACAP and VIP deficient mice was demonstrated an increase of locomotor activity in open field [56]. On the other hand, VPAC2 deficient mice have been shown to be more vulnerable to inductors of experimental colitis than their wild-type littermates [64]. Recently, a potential suitability of PACAP as a predictor of outcome from acute intracerebral ischaemia has been suggested by clinical studies [65] [66]. PACAP38/PAC1 signalling was demonstrated to be an important factor in regulation of trafficking of bone marrow cells which could facilitate their travel to vascular niches after focal cerebral ischaemia [66]. Already 2011 Ressler et al. [67] demonstrated that single nucleotide polymorphisms in the genes of PACAP (ADCYAP1) and PAC1 receptors (ADCYAP1R1) or methylation of the receptors mRNA can result in postischaemic stress disorder. Moreover, altered VIP levels have been described in obese women (low levels) and patients with anorexia nervosa [68] [69]. Furthermore, VIP is suggested to be involved in circuits regulating stimulation of the dentate subgranular stem cell niche and it is co-expressed by 
GABAergic neurons located in hippocampal regions close to this proliferatively important region [11]. For PACAP and VIP have been discovered direct and indirect neuroprotection via microglia mediated mechanisms (RANTES; CC chemokine Regulated upon Activation, Normal T cell Expressed and Secreted; MIP; macrophage inflammatory protein; ADNF; activity dependent neurotrophic factor) and for PACAP has been discussed a stimulation of chemokine release by microglia for inhibition of gp120 co-repressors like CCR3, CCR5 and CXCR4-a mechanism possibly of relevance for the protection against HIV [26] [70]. High attention has been paid to the presence of VIP in lung and bronchial tissue [71]-[73]. A high VIP content in the lung [74] was one of the main triggers of the ligand research on VPAC receptors.

\subsection{PAC and VPAC Receptors}

Most of the binding data on vasoactive intestinal peptide receptors were measured in cellular systems with overexpression of wild-type and mutated types of the three target receptors. For chicken PAC1 receptors Zawilska et al. [9] ranked the affinities of the endogenous peptides in the following order: PACAP38 PACAP27 > PACAP6-27 PACAP6-38 > chicken VIP (cVIP) > mammalian VIP and secretin (inactive) [9]. The highest density in chicken cortical membranes has been demonstrated with $457 \mathrm{fmol} / \mathrm{mg}$ for the PAC1 receptor [9] and in mouse whole brain membranes with $857 \mathrm{fmol} / \mathrm{mg}$ protein [75] using [ $\left.{ }^{125} \mathrm{I}\right]$-PACAP27 as receptor ligand. In guinea pig cerebral cortex maximal binding of [ $\left.{ }^{125} \mathrm{I}\right]$ VIP (human /rat/porcine) was reported by Zawilska et al. 2005 [76] with $77 \mathrm{fmol} / \mathrm{mg}$ protein without differentiation of the receptor subtypes and the authors provided relative rank order of potency: cVIP $\geq$ PACAP38 PACAP27 guinea pig VIP (gpVIP) $>$ mammalian VIP (mVIP) $>$ peptide-histidine-methionine $(\mathrm{PHM})>$ peptide-histidine-isoleucine $(\mathrm{PHI})>$ secretin [76]. Main localizations of PAC1 receptors are neurogenic regions like subventricular zone of olfactory bulb and dentate gyrus [10]. Immunohistochemical investigations suggest high levels of PAC1 receptors also in layer I of the cerebral cortex, very high density of the receptor in hypothalamus, brainstem, midbrain and hindbrain, and in cerebellar nuclei. [57] [58] [77].

In turn, PAC1 has been reported to be of less importance in hippocampal regions than VPAC receptors [75] [78].

Autoradiographic and membrane binding assay data as well as species differences have been described also for peripheral tissue [12]. Comparison of [ $\left.{ }^{125} \mathrm{I}\right]$ VIP binding at receptors of the lung in human and guinea pig tissues reveals $B_{\max }$ values of $11.2 \mathrm{fmol} / \mathrm{mg}$ protein and $226 \mathrm{fmol} / \mathrm{mg}$ protein, respectively, for the high affinity binding site and $589 \mathrm{fmol} / \mathrm{mg}$ protein and $1730 \mathrm{fmol} / \mathrm{mg}$ protein at the low affinity binding sites. For the rat lung have been reported $B_{\max }$ of $584 \mathrm{fmol} / \mathrm{mg}$ protein [73].

For PAC1 receptors in rodents (PACAP38, $\mathrm{K}_{\mathrm{d}} 0.5 \mathrm{nM}$, for comparison VIP-affinity $>500 \mathrm{nM}$ ) have been identified six splice variants relevant for the third intracellular loop which is coupled to G-proteins [79]. The two exons hip and hop, spliced in or out determine different PAC1 receptor variants triggering different signalling pathways [9] [24]. Moreover, splice variants with change in the a.a.r. sequence of the N-ted in position 21 have been described [5]-[7] which bind PACAP27, PACAP38 and VIP with similar affinity [5]-[7].

Activation pathways related to neuroproliferation are regulated via $G_{q}$ and $G_{i}$ proteins [80] and via interaction with mitogen-activated protein kinase MAP-Kinase and arrestins which provide the regulatory input to receptor internalization, desensitization and proteolytic processes as well as to heteromeric signal protein complex activation. The preferred binding sites of VIP are the N-teds of VPAC1 and VPAC2 receptors (K $1 \mathrm{nM})$ [81], which mediate their intracellular actions via $G_{s}$ proteins, but also via $G_{q}$ and $G_{0}$ proteins. They also trigger calcium release as well as interact with RAMP1-3 (receptor activity modifying protein) ( $c f$. Table 1). A differentiation between the VPAC receptor subtypes predominantly became possible by the discovery of helodermin obtained from gila monster venom [9] [82] [83]. The peptide shows some homology to PACAP and VIP.

Whereas Nicole et al. [59] had supplied a first systematic functional classification of VIP and PACAP a.a.r. components, Laburthe et al. (2007) [83] discussed critically basing on these data two different models of the mechanism in which VPAC receptors and especially its N-ted can transfer its endogenous ligands within the transmembrane/juxtamembrane domain (J-domain) of the receptor as well as close to intracellular loops (here IL3) involved in G proteins activation [84]-[86]. Endogenous peptide ligands [35] [87] [88] bind by their C-terminal portion to the extracellular domain whereas the N-terminus of the endogenous ligands interacts with the 7TMD structures of the receptors. All Class-B receptors are distinct from Class A receptors by the typically large N-ted (100 - 160 a.a.r, [36] [47]) with consensus repeat or Sushi domain core formed by two antiparallel $\beta$ sheets connected via three disulfide bonds between six cysteine residues and a salt bridge. This feature is re- 
garded as the signature of Class B receptors, even if a full length structure of Class B receptors is yet not available [61] [84].

VPAC1 is expressed in lung, small intestine, thymus, kidney and brain [10] [63] [78] [89] [90]. In the brain VPAC receptors are expressed in piriform cortex, cerebral cortex, dentate gyrus, hippocampus, lateral amygdaloid nucleus, caudate putamen, nucleus supraopticus, thalamic nuclei, choroid plexus and pineal gland as well as cerebellar cortex and deep cerebellar nuclei [11] [77]. $\mathrm{B}_{\max }$ values for the binding of $\left[{ }^{125} \mathrm{I}\right] \mathrm{CVIP}$ and $\left[{ }^{125} \mathrm{I}\right] \mathrm{PACAP}$ have been obtained for chicken hypothalamus and chicken cortical cerebral membranes respectively. $\left[{ }^{125} \mathrm{I}\right] \mathrm{CVIP}$ has been shown to bind with $167 \mathrm{fmol} / \mathrm{mg}$ protein to chicken hypothalamic membranes [8] 1/3 of the $B_{\max }$ for $\left[{ }^{125} \mathrm{I}\right]$ PACAP in cortical cerebral membranes of the same species [9].

Also the main target receptors of VIP as there are VPAC1 and VPAC2 have different pharmacology and distributions [5] [91]. E.g. VIP had a 4 fold higher affinity for hVPAC1 than for VPAC2 [60] [61].

The VPAC2 receptor is suggested to mediate activation of insulin secretion [91] [92], while VPAC1 receptors according to their expression pattern are suggested to contribute to the increase of hepatic glucose production [93]-[95] but also to attenuation of diabetes related inflammation [96].

On the other hand, [24] chromosomal site duplication can result in serious neuroanatomic retardation [24] and characteristic mental diseases, e.g. alterations of VPAC2 expression by chromosomal site duplication can carry the risk of schizophrenia and autism [97]. In turn, VPAC2 receptor-deficient mice showed growth retardation [98].

PAC1 knock-out mice have been reported to show mortality close to $60 \%$ during the first four weeks after birth. Surviving mice are characterized by a accelerated decrease in social investigations and less aggressively male animals but higher sexual activity. The experiments suggested that PACAP could be a counterpart of the vasopressin-oxytocin system [99]. Furthermore, PAC1 deficient mice were shown to develop reduction of anxiety-like behaviour [100].

\subsection{Synthetic Peptide Ligands}

Labelling of synthetic peptide ligands with PET and SPECT isotopes for recognition of VPAC and PAC receptors for diagnostic and therapeutic purposes include ${ }^{99 \mathrm{~m}} \mathrm{Tc},{ }^{18} \mathrm{~F},{ }^{123} \mathrm{I},{ }^{68} \mathrm{Ga},{ }^{64} \mathrm{Cu}$ and ${ }^{111} \mathrm{In}$ labelled compounds, which are prepared using distinct chelating agents or prosthetic groups [45]. Somatostatin and its labelled analogues (e.g. $\left[{ }^{111} \mathrm{In}\right]$ octreotide) are the most frequently clinically used peptides in tumor diagnostics. However, also further peptide receptor ligands are more and more in the focus of tumor visualization. E.g. bombesin peptides labelled with ${ }^{18} \mathrm{~F}$ and ${ }^{99 \mathrm{~m}} \mathrm{Tc}$ have been already described in studies with VPAC receptor ligands in the early years of this century. The overexpression of VPAC receptors, however, also in normal tissues of some organs restricts the efficiency of such peptide probes as tools in tumor identification [45]. Other applications e.g. the imaging of brain receptors are limited by vulnerability of the peptides to enzymatic breakdown and low in vitrostability. Some success could be achieved by reconstituted peptides containing mutations in selected parts of the molecule, intramolecular ring structures, introduction of lactam ringsor acylation of the N-terminus of VIP [101]. Furthermore, the connection with polyethylene glycol (PEG) was used to improve the pharmacokinetic properties.

\subsubsection{Peptide Ligands at VPAC1 Receptor}

Nicole et al. (2000) [59] observed, that alanine exchange of VIP a.a.r. in positions 11, 22 and 28 results in binding with $10^{-8} \mathrm{M}$ affinity at VPAC1 receptor what is close to the affinity of VIP itself. In contrast, the binding affinity at VPAC2 receptors decreases by one order of magnitude after such substitution. Consequently, $\left[\mathrm{Ala}^{11,22,28}\right]$ VIP is classified as the most selective agonist at human VPAC1 receptor.

Peptide ligands at VPAC1 receptors ( $c$. Table 2) attract attention predominantly as in vitro probes for the characterization of their target receptors but maintain in part also affinities to VPAC2 and PAC1 receptors. PG 96-238 and PG 97-465 are antagonist and agonist at the VPAC1 receptor, respectively, but also antagonist at VPAC2 and agonists at PAC1 receptor (cf. Table 2). PGI 97-278 is partial antagonist at the VPAC1 receptor and agonist at the VPAC2 receptor [101]. The extension of the VIP sequences VIP (1 - 24) or VIP (1 - 26) by the carboxyl terminal part of Ro 25-1553 (DLKKGGT or KKGGT) decreased the affinity at VPAC1 receptors but altered not the affinity at VPAC2 receptors.

\subsubsection{Peptide Ligands at VPAC2 Receptor}

For different therapeutic purposes some VIP and PACAP related peptides have been synthesized and shown to 
Table 2. Some peptide ligands of VPAC1, VPAC2 and PAC1 receptor ${ }^{*}$ and their role as agonists or antagonist at these receptors.

\begin{tabular}{|c|c|c|c|c|c|}
\hline Peptide & CAS-no & VPAC1R & VPAC2R & PAC1R & References \\
\hline VIP & 37221-79-7 & agonist & agonist & & [102] \\
\hline PG-96-237 & & & & & [101] \\
\hline PG 96-238 & 309728-48-1 & antagonist & antagonist & partial agonist & [95] \\
\hline PG 97-269 & 202463-00-1 & antagonist & & & [103] [104] \\
\hline PG 97-277 & 139308543 & partial agonist & & & [101] \\
\hline PG 97-278 & 1392912-99-0 & partial antagonist & agonist & & [101] \\
\hline PG 99-465 & 309913-26-6 & fullagonist & $\begin{array}{c}\text { antagonist } \\
\text { partial agonist }\end{array}$ & fullagonist & [47] [101] [104] [105] \\
\hline Bay 55-9837 & $46390-25-8$ & & agonist & & [10] [16] [55] [103] [106] \\
\hline Ro 25-1392 & $150828-75-4$ & & agonist & & [107] \\
\hline Ro 25-1553 & 159704-87-6 & & agonist & & [71] [102] \\
\hline [Ala11,22,28]VIP & & antagonist & & & [59] \\
\hline PACAP (6-38) & 143748-18.9 & antagonist & antagonist & antagonist & [47] [63] [104] [109] \\
\hline M65 & & & & antagonist & [109] \\
\hline Maxadilan & 515114-03-1 & & & agonist & [63] [110] [111] \\
\hline Maxadilan d.4 & & & antagonist & & [63] [110] [111] \\
\hline PACAP27 & 129069-75-6 & & & agonist & [109] \\
\hline PACAP38 & 137061-48-4 & & & agonist & [109] \\
\hline
\end{tabular}

*peptide sequences: VIP: HSDAVFTDNYTRLRKQMAVKKYLNSILN; PG 96-237: AcHSDAVFTENYTKLRKRNleAAKKYLNDLKKGGT; PG 96-238: -FTENYTKL-RKRNleAAKKYLNDLKKGGT (20-16)lactam; PG 97-269: AcHD-PheDAVFTNSYRKVLKRLSARKLLQDIL; PG 97-277: N-Ac-HSDAVFTENYTKLEKRNle-AAKNleYLNNLKKGG-threonine amide; PG 97-278: AcHDPheDAVFTENYTKLRKRNleAAKNleYLNNLKKGGT; PG 99-465: N-(1-oxotetradecyl) HSDAVFTDNYTKLRKQMAVKKYLNSIKKGGT; Bay 55-9837:

HSDAVFTDNYTRLRKQVAAKKYLQSIKNKRY; Ro 25-1392: AcHSDAVFTEN-O-methyl-YTKLRKQNleAAKKYLNDLKK(25-21)lactam; Ro 25-1553: AcHSDAVFTENYTKLRKQNleAAKKYLNDLKKGGT;PACAP (6-38):

TDSYSRYRKQMAVKKYLAAVLGKRYKQRVKNK; M65: CDATCQFR-KAIDDCQKQAHHSN-VLLPGNSVFKECMKQKKKEFKAGK;

Maxadilan: ATCQFRKAIDDCQKQAHHSNVLQTSVQTTATFTSMDTSQLPGNSVFKECMKQKKKEFKAGK;

Maxadilan d.4: CDATCQFRKAIDDCQKQAHHSNV-PGNSVFKECMKQKKKEFKAGK;

PACAP27: HSDGIFTDSYSRYRKQMAVKKYLAAVL; PACAP38: HSDGIFTDSYSRYRKQMAVKKYLAAVLGKRYKRYKQRVKNK

interact with VPAC2 receptors. This is not only limited to tumor diagnostics but include also applications in metabolic diseases. Thus the possibility of a decrease of glucose levels has been investigated. The peptide BAY 55 - 9837 had been identified as an effective glucose suppressing compound by an agonist action via VPAC2 receptors. [16] [106]. However, the compound showed degradation at the N-terminus and deamidation at asparagine [106]. Pan et al. could improve the stability by mutations in the positions 9 and 28 and obtained BAY (Q9Q28) which showed the same affinity at VPAC2 receptors like the original compound. However, it was stable for four weeks at $40^{\circ} \mathrm{C}$, while BAY 55 - 9837 was degradated by $80 \%$ within two weeks. Coupling the reconstituted compound via the cysteine residue C32 to polyethylene glycol (22 or $43 \mathrm{kDa}$ ) resulted in stable compounds. Best conservation of the in vitro functionality after pegylation was observed with 22 kDA polyethylene glycol. Both pegylated forms were active in vivo, for three and six hours post s.c. injection. General in vivo action was improved and the glucose lowering effect was maintained, while in vitro activities were reduced by pegylation. Mutations in the first a.a.r.s of the N-terminus resulted in reduced flexibility of the ectodomain and consequently a reduced affinity at VPAC2 receptors [106].

BAY55-9837 has been proposed recently as a potential protective drug in spinal muscular atrophy in distinct mouse models [112]. Spinal muscular atrophy is a rare disease (incidence 1:11,000) but a leading genetic cause of pediatric death [112] [113]. BAY 55-9837 is presumed to activate via binding at VPAC2 receptors the p38 pathway and to enhance the Survival of Motor Neuron proteins (SMN) type 2 inhibiting the progression of spin- 
al muscular atrophy [108].

All the peptide ligands bind orthosterically at the N-terminal ectodomain of their target receptors [47]. But that makes it difficult to develop highly selective ligands for the subtypes of VPAC receptors due to the similarities between the peptides [47].

The long-acting VIP analogue Ro 25 - 1553 is a peptide with lactam ring at the amino acids 21 to 25 [95]. The absence of the lactam bridge in the molecule reduced the affinity of the compound at both subtypes of VPAC receptors, but retained a 300 fold selectivity for binding to VPAC2 receptor [94]. This was presumed to be due to charged side chains revealed in these compounds under such conditions. Such consequence could be prevented by introduction of a nor-leucine and an asparagine residue at the positions 21 and 25 [101]. Ro 25-1553 was early tested in forebrain membranes [72] where it could displace [ $\left.{ }^{125} \mathrm{I}\right] \mathrm{VIP}$ with an $\mathrm{IC}_{50}$ of $4.98 \mathrm{nM}$. The cyclic VIP analogue got especially early attention for its relaxant effect on bronchotracheal tissues in guinea pigs and humans [71] [72]. Since 2003 these effects comparable with that of isoproterenol and salbutamol were confirmed also in clinical studies [114]. The comparison of the influence of Ro 25-1553 on bronchial and lung function with that of salbutamol revealed an equivalent degree of both drugs in protection of pulmonary tissue [70]. In guinea pig and human isolated bronchial tissue Ro25 - 1553 could attenuate brochoconstriction induced by histamine, LTD4, platelet activating factor or acetylcholine [71]. A further cyclic peptide, Ro 25 - 1392, displaced $\left[{ }^{125} \mathrm{I}\right]$ VIP with $\mathrm{K}_{\mathrm{i}}$ of 9.6 and $16 \mathrm{nM}$ at VPAC2 receptors whereas the affinity at VPAC1 receptors was in $\mu \mathrm{M}$ range [17] and only $40 \%$ of VPAC receptors the binding sites could be occupied.

\subsubsection{Peptide Ligands at PAC1 Receptor}

For PACAP38 it is known that deletion of the first five a.a.r.s of the peptide transforms it from an agonist to an antagonist at the receptor [58]. Mutational and binding data confirm an essential role of these a.a.r.s in the orthosteric binding of the C-terminus of the endogenous agonist at the N-terminal ectodomain of the receptor and a role of further parts of the peptide in the transfer into vestibular or transmembrane domain of receptor [58] [61].

The 61 a.a.r. peptide Maxadilan can be obtained from blood seeking flies as lutzomyia longipalpis [101] [115] but is available today also as synthetic compound. As a vasodilator with higher efficacy than CGRP it plays a role in the infectivity pathway of leishmania conducted by sand fly and does not show close structural similarity to PACAP [111] [116]. Maxadilan acts as an agonist at the PAC1 receptor (Table 2). Additionally to the actions on vascular tone of arteriolar vessels recently an enhancement of vascular leakage in postcapillary vessels and venuels has been described accompanied by a stimulation of leucocyte migration via the CXCR1/2 receptor of neutrophils [116]. All these actions are suggested to be mediated via PAC1receptors and can be attenuated by the recombinant analogue of Maxadilan, M65 [116].

\section{Non-Peptide Ligands of VPAC and PAC Receptors}

Until 2010 small molecule ligands had been identified for five of the 15 known Class B GPCRs only [47] [117]. Such were antagonists of the CRF1 receptor as SSR125543A, antalarmin, DMP 904, NBI 30775/R121919, NBI 35965; antagonists at the glucagon receptor as LY 168049, BAY 27 - 9955, NNC25 - 2504;, an antagonist at the CGRP receptor: BIBN4096BS; the GLP-1 receptor antagonist T0632 and the calcitonin receptor agonist SUNB8155 [85] [117]. However, these compounds have been discussed rather as allosteric modulators than as drugs docking orthosterically and acting competitively [117]. Also for the CGRP receptor ligand MK4232, described 2013 by Hostetler et al. [30], in first successful PET experiments binding modalities in the brain let open questions even if the compound was bound to the parts of the brain in a manner reflecting the regions typically showing high densities of the receptor [118]. The involvement of non-peptide ligands at VPAC and PAC receptors might extend the spectrum of tracers contributing to the characterization of functional basis of mental diseases and of responses to therapeutic interventions in neurological disorders. It is not finally decided which of the recent models [61] [119] for ligand-class $C$ receptor interaction could be a relevant one for the explanation of non-peptide ligand actions.

\subsection{Non-Peptide VPAC1 Receptor Ligands}

There had been no reports on small molecule non-peptide ligands of the VPAC1 receptor until Harikrishnan et al. (Bristol-Myers Squibb) [90] published 2012 the results of a high throughput screening based on cAMP as- 
says and determination of antiproliferative activity. Three series of potential lead structures were presented providing moderate binding affinities until $81 \mathrm{nM}$ (biaryl compounds; Figure 3, compounds 1 - 3); $290 \mathrm{nM}$ (cyanothiophenes; Figure 4, compounds 4 - 8) and $410 \mathrm{nM}$ (cyanothiophene phenethylamide) compounds 9 and 10; Figure 5).<smiles>CC(C)(C)C1CC(CO)C(CO)C(c2ccc(F)cc2)C1</smiles><smiles>CC(C)(C)C1CC(CO)C(CO)C(c2cccc(Cl)c2)C1</smiles><smiles>Cc1ccc(C2CC(C(C)(C)C)CC(C(C)(C)C)C2CO)cc1C</smiles>

Figure 3. Non-peptide ligands of VPAC1 receptors: Biaryl compounds: 1. (2,4-di-tert-butyl-6-(4-fluorophenyl) cyclohexyl) methanol; 2. (2,4-di-tert-butyl-6-(4-chlorophenyl) cyclohexyl) methanol; 3. (2,4-die tert-butyl-6-(3,4-dimethylphenyl)-chlorophenyl) cyclohexyl) methano. ChemDraw (Cambridgesoft.com) was used for verification of IUPAC names.<smiles>CC(O)=Nc1sc2c(c1C#N)CCCC2</smiles><smiles>N#Cc1c(/N=C(\O)C2CCCC2)sc2c1CCCC2</smiles><smiles>N#Cc1c(/N=C(/O)C2CCCCC2)sc2c1CCCC2</smiles><smiles>N#Cc1c(/N=C(/O)c2ccccc2)sc2c1CCCC2</smiles><smiles>C/C(F)=N\c1sc2c(c1C#N)CCCC2</smiles>

Figure 4. Non-peptide ligands of VPAC1 receptors: Cyanothiopentenes: 4.(E)-N-(3-cyano-4,5,6,7-terahydrobenzo[b] thiophen-2-yl)acetimidic acid; 5. (E)-N-(3-cyano-4,5,6,7-tera-hydro- benzo-[b]thiophen-2-yl) cyclopentane carbimidic acid; 6. (E)-N-(3-cyano-4,5,6,7-terahydro-benzo[b]thiophen-2-yl) cyclohexane carbimidic acid; 7. (E)-N-(3-cyano-4,5,6,7-terahydrobenzo[b]thiophen-2-yl) benzimidic acid; 8.(E)-N-(3-cyano-4,5,6,7-terahydrobenzo[b]thiophen-2-yl) acetimidoyl fluoride. 


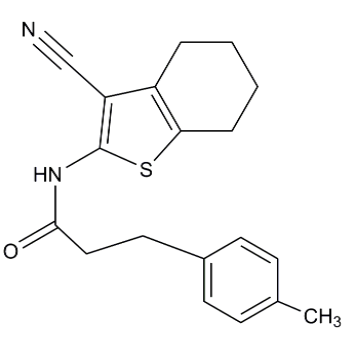

9

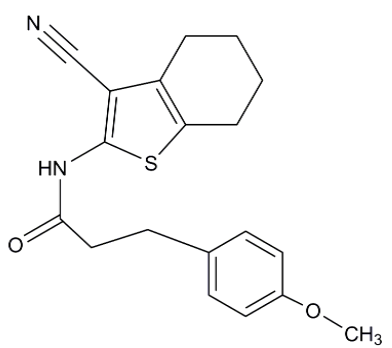

10

Figure 5. Non-peptide ligands of VPAC1 receptors: Propanamide substituted cyanothiophenes: 9. N-(3-cyano-4,5,6,7-tetrahydrobenzo [b]thiophe-2-yl)-3-(p-tolyl)propanamide; 10. N-(3-cyano-4,5,6,7-tetrahydrobenzo[b]thiophen-2yl)-3-(4-methoxyphenyl)propanamide.

Robl et al. provided in 1990 [120] the synthetic route used by Harikrishnan et al. in a modified mode via formation of a lactone and its aromatization followed by introduction of triflic anhydride which gave via aryl triflate finally the biaryl. A series of substitutions at the 2-aryl ring resulted in the best $\mathrm{IC}_{50}$ values for a 3-chloro compound $(100 \mathrm{nM})$ and a 3,4 dimethyl compound $(81 \mathrm{nM})$ regarding inhibition of cAMP release. Actions on cell proliferation could not be verified.

The cyanothiophenes stood less active in the same screening assays if various amides had been introduced into the molecules. In general, the introduction of amides coupled to cyclopentyl and hexyl residues resulted in better IC $_{50}$ (until $290 \mathrm{nM}$ ) than the small aliphatic or small cyclic motifs. Further modification of phenetylamide cyanothiophenes (Figure 5) could not further improve the inhibitory efficacy in cAMP assays additionally [90].

\subsection{Non-Peptide VPAC2 Receptor Ligands}

Neither orthosterically nor allosterically binding small molecule ligands of VPAC2 receptors were presented until 2010 [47]. The first compound discovered by high throughput screening was a nitrophenyl sulfonamide pentanamide which showed moderate $\mathrm{IC}_{50}$ values for inhibition of VPAC2 receptor-mediated cAMP accumulation ( $\mathrm{IC}_{50} 3.8 \mu \mathrm{M}$ ) and for ligand-activated $\beta$-arrestin2 binding ( $\mathrm{IC}_{50} 2.3 \mu \mathrm{M} ; \beta$ arrestin Pathhunter assay). Chu et al. (Novartis) pronounciate that only a single lead structure was detected among 1.67 million compounds of their data collection. This compound is a non-competitive ligand of the human VPAC2 receptor [47] (Figure 6, compound 11).

One of the main obstacles of the discovery of the small-molecule ligands of class B GPCRs is the absence of highly pecific antagonists at VPAC1 and VPAC2 receptors [47]. Peptide ligands typically bind to orthosteric binding sites of these receptors. However, usually the structural difference between such peptide ligands are not sufficient to discriminate very selectively between the two receptor subtypes. Chu et al. demonstrated for their compound in Schild-Plot analysis of cAMP accumulation typical features of non-competitive ligands as the mismatch of the slope with requirements for perfect linear regression which would have confirmed competitive interaction with the VPAC2 receptor.

In the $\beta$-arrestin assay compound 1 (here compound 11, $c f$. Figure 6) decreased $\mathrm{EC}_{50}$ of VIP but reduced also the maximal level of arrestin binding what fulfills rather the requirements for an allosteric modulator than for a competitive antagonist. The compound interacts with a.a.r. in the TM7 region which are, however, not conserved between human and mouse [47] [84].

Compound 2 (here compound 12, Figure 6) is presumed by Chu et al. [47] to activate the VPAC2 receptor rather than to act as an antagonist.

\subsection{Non-Peptide PAC1 Receptor Ligands}

A first series of small-molecule antagonists of PAC1 receptors with affinities in the nM range was proposed in 2008 by Beebe et al. (Abbott Laboratories) [46]. Hydrazides were chosen as lead structures containing three cyclic moieties and the authors of the study supplied also first landmarks on potential pharmacophore contributions of the essential parts of these compounds [25]. Identification of two lead structures was performed by means of a compound library using $\left[{ }^{125} \mathrm{I}\right] \mathrm{PACAP} 27$ binding at PAC1 receptors expressed in human embryonic 


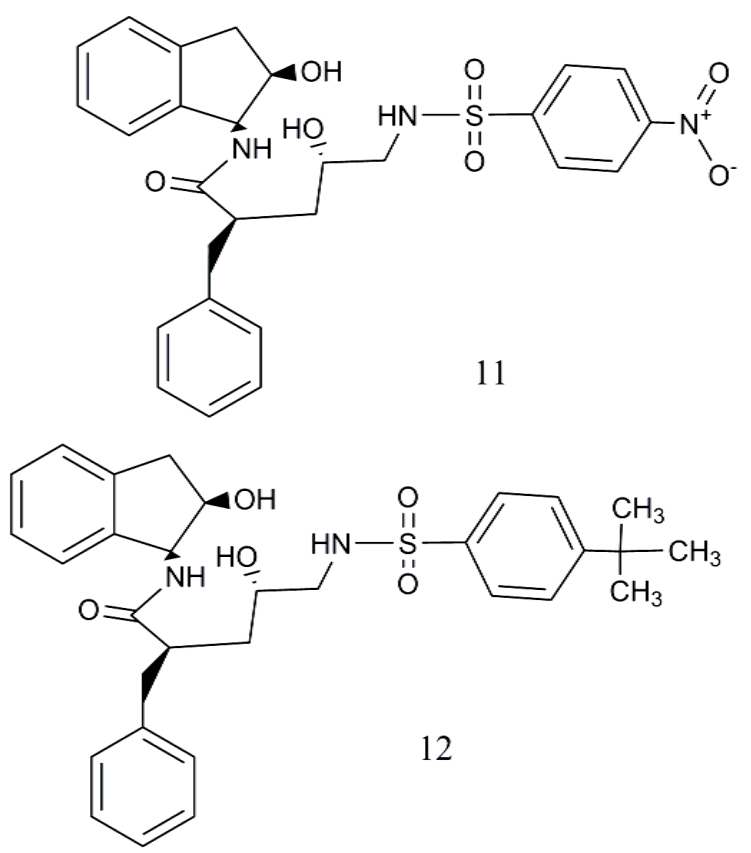

Figure 6. Non-peptide ligands of VPAC2 receptors: Pentanamides: 11. (2R, 4S)-2-benzyl-5-((4(tert-butyl)phenyl)sulfonamido)-4-hydroxy-N-(1S,2R)-2-hydroxy-2,3-dihydro-1H-inden-1yl)pentanamide; 12. (2R, 4S)-2-benzyl-4-hydroxy-N-(1S, 2R)-2-hydroxy-2,3-dihydro-1H-inden-1yl)5((4-nitrophenyl)sulfonamide)pentanamide.

kidney cells (HEK293f cells). Finally, the structures based on series of alkylidene hydrazides developed by Madsen, Ling et al. (Novo-Nordisk ,Pfizer) as glucagon receptor antagonists in 2002 [121]. Most effective binding potencies at the PAC1 receptor had been observed for a hydrazide (Figure 7, compound 13) with a $\mathrm{K}_{\mathrm{i}}$ of $56 \mathrm{nM}$ and a hydrazide indole (Figure 7, compound 16, $\mathrm{K}_{\mathrm{i}} 72 \mathrm{nM}$ ) [25] [46].

The $\log \mathrm{P}$ of compounds 13 and 16 are with 5.36 and 6.12 not in an appropriate range for use as probes for brain imaging. Modifications of the structure with demethylation in the distal ring, at the middle ring and fluorination at the distal ring can bring the ratio closer to 3 (Figure 7, 15). Beebe et al. [46] revealed in investigations of structure-activity relationships that alterations in these regions will be only of minor consequences for the affinity at the PAC1 receptor.

Furthermore, the pharmacophore analysis of hydrazide indoles described by Beebe et al. demonstrates the indole moiety tolerates only poor structural modifications. The p-phenol connected by the hydrazide linker with the middle ring as well as its m-electron withdrawing group had been identified to be crucial for high potency of the compound at the target receptor [46].

Currently, Wu et al. [25] investigated the potential interaction between the PAC1 receptor and its endogenous ligand PACAP38 as well as with the two hydrazides mentioned above (compounds 13 and 16; Figure 7). In docking studies of a 3D model of the receptor, the 7TMD of the PAC1 receptor was mimicked by a structure based on homology studies on the PTH1 receptor. The signal sequence of the $\mathrm{N}$-terminal ectodomain (N-ted) had been removed in this model [25] [122]. Previous experiments with exon 2 -/- mice had demonstrated that animals with targeted deletion of the signal peptide are viable, fertile and without morphological differences to wild-type animals [122] [123]. 76 and 89 conformations were identified for the binding of compounds 13 and 16 at the receptor model. In most of them hydrogen bonds were created to the amino acids I63, S100 and G105. Best binding conditions were obtained for compound 13 via hydrogen bonds with S100 and E339. The amino acid residues 116 - 120 of the N-ted domain had been identified as preferred binding sites of PACAP38. Because the signal peptide containing the first 20 amino acids is absent in the model created by Wu et al., the S100 corresponds to S120 in the native receptor [125]. The authors predicted that the investigated hydrazide compounds can inhibit the interaction of PACAP with the N-ted and prevent also the normal conformational consequences for the 7TMD region. They suggested that the compounds produce a steric hindrance for the binding of PACAP and inhibit competitively the biological activity of the peptide ligand. 
<smiles>COc1cc(/C=N/NC(=O)c2ccc(O)c(Cl)c2)cc(OC)c1OCc1ccc(C(C)C)cc1</smiles><smiles>COc1cc(/C=N/NC(=O)c2ccc(O)c(Cl)c2)cc(OCc2ccc(C(C)C)cc2)c1OC</smiles><smiles>COc1c(O)cc(/C=N/NC(=O)c2ccc(O)c(Cl)c2)cc1OCc1ccc(F)cc1</smiles><smiles>Cc1cc(C)c(C)c(Cn2ccc3c(/C=N/NC(=O)c4ccc(O)c(C#N)c4)cccc32)c1C</smiles>

Figure 7. Non-peptide ligands of PAC1 receptors: Hydrazides and hydrazide indoles: 13. (E)-3-chloro-4-hydroxy-N'-(4((4-isopropylbenzyl)oxy)-3,5-dimethoxybenzylidene) benzohydrazide; 14. (E)-3-chloro-4-hydroxy-N'-(3-((4-isopropylbenzyl)oxy)-4,5-dimethoxybenzylidene) benzohydrazide;15. (E)-3-chloro-N'-(3-((4-fluorobenzyl)oxy) 5-hydroxy-4-methoxybenzylidene)-4-hydroxybenzohydrazide; 16. (E)-3-cyano-4-hydroxy-N'((1-(2,3,5,6-tetramethylbenzyl)-1H-indol-4-yl) methylene) benzohydrazide.

\section{Summary and Conclusions}

Already early in vivo PET experiments with potential ligands at Class B receptors of the brain revealed pharmacodynamic constraints for non-peptide ligands in comparison with endogenous peptide ligands of these receptors [27] [123] [124]. E.g. investigations on CRF1 receptors using Br-76 and C-11 labelled compounds resulted in confined ligand binding and receptor occupancy in the brain which was not sufficient for in vivo visualization of regions with enrichment of such receptors.

Jagoda et al. discussed that related to their 4- $\left[{ }^{76} \mathrm{Br}\right]$ BMK-152 experiments in monkeys [123], non-peptide, small-molecule ligands would be expected to target the juxtamembrane domain (J-domain) either in allosteric or competitive manner, depending on conformation of the receptor, but at the extracellular domain they were presumed to obey to an allosteric mode only [85] [123]. For instance, antalarmin, a well known CRF1 antagonist, can trigger $G_{s}$ or $G_{i}$ proteins via binding to different states of the J-domain as preferred target structure [117]. Finally, the action of small-molecule non-peptide ligands is not ensuring the standard behaviour of the models described by Laburthe [84]. Even the most of the small-molecule compounds reported currently are not free of the pharmacodynamic drawbacks preventing high affinity ligand-receptor interactions comparable to that of endogenous peptide ligands.

Hollenstein (2014) suggested that the problems with small molecules were due to the large cave of the N-ted 
of Class B receptors which can bind the natural peptides and facilitate their approach to the activation motif in a region surrounded by the transmembrane domains [33] [36]. Extracellular domains, especially the $\mathrm{N}$-ted of Class B receptors are regarded to be not well conserved in comparison to Class A receptors, while there is a higher conservation of transmembrane domains (TMD) [125]-[129]. More and more small-molecule ligands are described with their TMD binding sites. For instance, Hollenstein currently described the TM3 domain as a binding site of a CRF1 ligand [33] [36]. A further potential target site for receptor probes might be at accessory proteins like RAMPs ( $c f$. Table 1 ) which are colocalized with Class B receptors [42]. For calcitonin gene-related peptide receptors forming a complex with CLR (calcitonin receptor like receptor) and RAMP1 has been shown that the CLR-RAMP1 heterodimer can interact with the small molecule CGRP receptor ligands olcegepant and telcagepant [36] [124]. RAMPs have been shown to be involved also in the actions of CRF1 receptor [38]; adrenomedullin, amylin, PTH, VPAC and glucagon receptor ( $c f$. Table 1). Relations of small molecules to RAMP structures at PAC and VPAC receptors have yet not been investigated. It is known for Class A receptors that allosteric interactions with extracellular loops between transmembrane domains of GPCRs can also influence the cooperativity of the respective domains and finally of the receptors e.g. mAch receptor [127] [130] [131]. Such options could be relevant also in Class B receptors.

The PAC1 receptor is regarded as the most abundant among the three receptors sensitive to PACAP and VIP. That's why the confirmation of a competitive binding mode of the hydrazides and hydrazide indoles described by Beebe et al. [46] could be an important step to suitable probes for in vivo imaging.

However, from the view of pharmacodynamics, the proposed small molecules are yet not able to compete with endogenous peptide ligands. Regarding efforts to use such compounds as PET tracers for in vivo visualization of PAC or VPAC receptors of the brain, they have to be ranged on a pre-stage of preclinical testing at the moment. A pharmacophore model like that developed by Beebe et al. might be a good starting point for the improvement and balanced selection of pharmacodynamically and pharmacokinetically relevant alterations of the molecules. Docking studies as described by Wu et al. [25] support the further improvement of the preliminary lead structures for potential VPAC and PAC receptor ligands and for the selection of best candidates for preclinical characterizations and labelling. Site directed mutations as well as knock-out or transgene animal models [134] will be helpful tools for better understanding of structure-function relationships as well as in evaluation of therapeutic efficacy of potential drugs. But for all of the potential ligands currently available the affinities are beyond the requirements allowing in vivo imaging of neuropeptide receptors. The improvement as well as the characterization of the selectivity for the target receptors of PACAP and VIP and their subtypes remains a challenge.

\section{Acknowledgements}

The author would like to thank Rike Preiß for the excellent technical assistance in the preparation of the manuscript and Ulrich Disko for repeated helpful advice.

\section{References}

[1] Said, S.I. and Mutt, V. (1970) Polypeptide with Broad Biological Activity: Isolation from Small Intestine. Science, 169, 1217-1218. http://dx.doi.org/10.1126/science.169.3951.1217

[2] Said, S.I. and Mutt, V. (1972) Isolation from Porcine-Intestinal Wall of a Vasoactive Octacosapeptide Related to Secretin and to Glucagon. European Journal of Biochemistry, 28, 199-204. http://dx.doi.org/10.1111/j.1432-1033.1972.tb01903.x

[3] Miyata, A., Arimura, A., Dah, R., Minamino, N., Uehara, A., Jiang, L., Culler, M.D. and Coy, D.H. (1989) Isolation of a Novel 38 Residue-Hypothalamic Polypeptide Which Stimulates Adenylate Cyclase in Pituitary Cells. Biochemical and Biophysical Research Communications, 164, 567-574. http://dx.doi.org/10.1016/0006-291X(89)91757-9

[4] Miyata, A., Jiang, L., Dahl, R.D., Kitada, C., Kubo, K., Fujino, M., Minamino, N. and Arimura, A. (1990) Isolation of a Neuropeptide Corresponding to the N-Terminal 27 Residue of the Pituitary Adenylate Cyclase Activating Polypeptide with 38 Residue (PACAP38). Biochemical and Biophysical Research Communications, 170, 643-648. http://dx.doi.org/10.1016/0006-291X(90)92140-U

[5] Harmar, A.J., Arimura, A., Gozes, I., Journot, L., Laburthe, M., Pisegna, J.R., Rawlings, S.R., Robberecht, P., Said, S.I., Sreedharan, S.P., Wank, S.A. and Waschek J.A. (1998) International Union of Pharmacology. VIII Nomenclature of Receptors for Vasoactive Intestinal Peptides and Pituitary Adenylate Cyclase Activating Polypeptide. Pharmacological Reviews, 50, 265-270. 
[6] Harmar, A.J., Fahrenkrug, J., Gozes, I., Laburthe, M., May, V., Pisegna, J.R., Vaudry, D., Waschek, J.A. and Said, S.I. (2012) Pharmacology and Functions of Receptors for Vasoactive Intestinal Peptide and Pituitary Adenylate CyclaseActivating Polypeptide: IUPHAR Review 1. British Journal of Pharmacology, 166, 4-17. http://dx.doi.org/10.1111/j.1476-5381.2012.01871.x

[7] Harmar, A.J., Marston, H.M., Shen, S., Spratt, C., West, K.M., Sheward, W.J., Morrison, C.F., Dorin, J.R., Piggins, H.D., Reubi, J.C., Kelly, J.S., Maywood, E.S. and Hastings, M.H. (2012) The VPAC2 Receptor Is Essential for Circadian Function in the Mouse Suprachiasmatic Nuclei. Cell, 109, 497-508. http://dx.doi.org/10.1016/S0092-8674(02)00736-5

[8] Gonzales, S.M., Kawashima, M., Kamiyoshi, M., Tanaka, K. and Ichinoe, K. (1995) Presence of Vasoactive Intestinal Peptide Receptor in the Hen Hypothalamus. Endocrine Journal, 42, 179-186. http://dx.doi.org/10.1507/endocrj.42.179

[9] Zawilska, J.B., Niewiadomski, P. and Nowak, J.Z. (2003) PAC1 Receptors in Chick Cerebral Cortex: Characterization by Binding of Pituitary Adenylate Cyclase-Activating Polypeptide, $\left[{ }^{125} \mathrm{I}\right]$-PACAP27. Neuroscience Letters, 338, 155158. http://dx.doi.org/10.1016/S0304-3940(02)01397-6

[10] Vaudry, D., Falluel-Morel, A., Bourgault, S., Bassile, M., Burel, D., Wurtz, O., Fournier, A., Chow, B.K.C., Hashimoto, H., Galas, L. and Vaudry, H. (2009) Pituitary Adenylate Cyclase-Activating Polypeptide and Its Receptors: 20 Years after the Discovery. Pharmacological Reviews, 61, 283-357. http://dx.doi.org/10.1124/pr.109.001370

[11] Zaben, M.J. and Gray, W.P. (2013) Neuropeptides and Hippocampal Neurogenesis. Neuropeptides, 47, 431-438. http://dx.doi.org/10.1016/j.npep.2013.10.002

[12] Castairs, J.R. and Barnes, P.J. (1986) Visualization of Vasoactive Intestinal Peptide Receptors in Human and Guinea Pig Lung. Journal of Pharmacology and Experimental Therapeutics, 239, 249-255.

[13] Diané, A., Payn, G.W. and Gray, S.L. (2014) Multifaces of Pituitary Adenylate Cyclase-Activating Polypeptide (PACAP): From Neuroprotection and Energy Homeostasis to Respiratory and Cardiovascular Systems. Journal of Metabolic Syndrome, 3, 162. http://dx.doi.org/10.4172/2167-0943.1000162

[14] Nakajima, E., Walkup, R.D., Fuji, A., Shearer, T.R. and Azuma, M. (2013) Pituitary Adenylate Cyclase-Activating Peptide Induces Neurite Outgrowth in Cultured Monkey Trigeminal Ganglion Cells: Involvement of Receptor PAC1. Molecular Vision, 19, 174-183.

[15] Delgado, M. and Ganea, D. (2003) Vasoactive Intestinal Peptide Prevents Activated Microglia-Induced Neurodegeneration under Inflammatory Conditions: Potential Therapeutic Role in Brain Trauma. FASEB Journal, 17, 1922-1924. http://dx.doi.org/10.1096/fj.02-1029fje

[16] Tsutsumi, M., Claus, T.H., Liang, Y., Li, Y., Yang, L., Zhu, J., Dela Cruz, F., Peng, X., Chen, H., Yung, S.L., Hamren, S., Livingston, J.N. and Clark, Q.P. (2002) A Potent and Highly Selective VPAC2 Agonist Enhances Glucose-Induced Insulin Release and Glucose Disposal. A Potential Therapy for Type 2 Diabetes. Diabetes, 51, 1453-1460. http://dx.doi.org/10.2337/diabetes.51.5.1453

[17] Frechilla, D., Garcia-Osta, A., Palacios, S., Cenarruzabeitia, E. and Del Rio, J. (2011) BDNF Mediates the Neuroprotective Effect of PACAP-38 on Rat Cortical Neurons. Neuroreport, 12, 919-923. http://dx.doi.org/10.1097/00001756-200104170-00011

[18] Couvineau, A., Ceraudo, E., Tan, Y.-V., Nicole, P. and Laburthe, M. (2012) The VPAC1 Receptor: Structure and Function of a Class B GPCR Prototype. Frontiers in Endocrinology, 3, 139. http://dx.doi.org/10.3389/fendo.2012.00139

[19] Otto, C., Hein, L., Brede, M., Jahns, R., Engelhardt, S., Gröne, H.-J. and Schütz, G. (2004) Pulmonary Hypertension and Right Heart Failure in Pituitary Adenylate Cyclase-Activating Polypeptide Type 1 Receptor Deficient Mice. Circulation, 110, 3245-3251. http://dx.doi.org/10.1161/01.CIR.0000147235.53360.59

[20] Faraone, S.V., Skol, A.D., Tsuang, D.W., Young, K.A., Haverstock, S.L., Prabhudesai, S., Mena, F., Menon, A.S., Leong, L., Sautter, F., Baldwin, C., Bingham, S., Weiss, D., Collins, J., Keith, T., Vanden Eng, J.L., Boehnke, M., Tsuang, M.T. and Schellenberg, G.D. (2005) Genome Scan of Schizophrenia Families in a Large Veterans Affairs Cooperative Study Sample: Evidence for Linkage to 18p11.32 and for Racial Heterogeneity on Chromosomes 6 and 14. American Journal of Medical Genetics Part B: Neuropsychiatric Genetics, 139B, 91-100. http://dx.doi.org/10.1002/ajmg.b.30213

[21] Hashimoto, R., Hashimoto, H., Shintani, N., Chiba, S., Hattori, S., Okada, T., Nakajima, M, Tanaka, K., Kawagishi, N., Nemoto, K., Mori, T., Onishi, T., Noguchi, H., Hori, H., Suzuki, T., Iwata, N., Ozaki, N., Nakabayashi, T., Saitoh, O., Kosuga, A., Tatsumi, M., Kamijima, K., Weinberger, D.R., Kunugi, H. and Baba, A. (2007) Pituitary Adenylate Cyclase Activating Polypeptide Is Associated with Schizophrenia. Molecular Psychiatry, 12, 1026-1032. http://dx.doi.org/10.1038/sj.mp.4001982

[22] Vaudry, D., Gonzalez, B.J., Basille, M., Yon, A., Fournier, A. and Vaudry, H. (2000) Pituitary Adenylate CyclaseActivating Polypeptide and Its Receptors: From Structure to Functions. Pharmacological Reviews, 52, $269-324$. 
[23] Kumar, S., Pioszak, A., Zhang, C., Swaminathan, K. and Xu, H.E. (2011) Crystal Structure of the PAC1R Extracellular Domain Unifies a Consensus Fold for Hormone Recognition by Class B G-Protein Coupled Receptors. PLoS ONE, 6, e19682. http://dx.doi.org/10.1371/journal.pone.0019682

[24] Shen, S, Gehlert, D.R. and Collier, D.A. (2013) PACAP and PAC1 Receptor in Brain Development and Behavior. Neuropeptides, 47, 421-430. http://dx.doi.org/10.1016/j.npep.2013.10.005

[25] Wu, L., Guang, W., Chen, X. and Hong, A. (2014) Homology Modeling and Molecular Docking of Human Pituitary Adenylate Cyclase-Activating Polypeptide I Receptor. Molecular Medicine Reports, 10, 1691-1696. http://dx.doi.org/10.3892/mmr.2014.2419

[26] Dejda, A., Sokolowska, P. and Nowak, J.Z. (2005) Neuroprotective Potential of Three Neuropeptides. Pharmacological Reports, 57, 307-320.

[27] Sullivan, G.M., Parsey, R.V., Kumar, J.S.D., Arango, V., Kassir, S.A., Huang, Y.-Y., Simpson, N.R., van Heertum, R.L. and Mann, J.J. (2007) PET Imaging of CRF1 with $\left[{ }^{11} \mathrm{C}\right] \mathrm{R} 121919$ and $\left[{ }^{11} \mathrm{C}\right] \mathrm{DMP} 696$ : Is the Target of Sufficient Density? Nuclear Medicine and Biology, 34, 353-361. http://dx.doi.org/10.1016/j.nucmedbio.2007.01.012

[28] Zorilla, E.P. and Koob, G.F. (2010) Progress in Corticotrophin Releasing Factor 1 Antagonist Development. Drug Discovery Today, 15, 371-383. http://dx.doi.org/10.1016/j.drudis.2010.02.011

[29] Kehne, J.H. and Cain, C.K. (2010) Therapeutic Utility of Non-Peptidic CRF1 Receptor Antagonists in Anxiety, Depression and Stress-Related Disorders: Evidence from Animal Models. Pharmacology \& Therapeutics, 128, 460-487. http://dx.doi.org/10.1016/j.pharmthera.2010.08.011

[30] Hostetler, E.D., Joshi, A.D., Sanabria-Bohorquez, S., Fan, H., Zeng, Z., Purcell, M., Gantert, L., Riffel, K., William, M., O’Malley, S., Miller, P., Selnick, H.G., Gallicchio, S.N., Bell, I.M., Salvatore, C., Kane, S.A., Li, C.C., Hargreaves, R., de Groot, T., Bormans, G., van Hecken, A., Derdelinckx, I., de Hoon, J., Reynders, T., Declercq, R., de Lepeleire, I., Kennedy, W.D., Blanchard, R., Marcantonio, E.E., Sur, C., Cook, J.J., van Laere, K. and Evelhoch, J.L. (2013) In Vivo Quantification of Calcitonin Gene-Related Peptide Receptor Occupancy by Telcagepant in Rhesus Monkey and Human Brain Using the Positron Emission Tomography Tracer $\left[{ }^{11} \mathrm{C}\right] \mathrm{MK}-4232$. Journal of Pharmacology and Experimental Pharmaceutics, 347, 478-486. http://dx.doi.org/10.1124/jpet.113.206458

[31] Shoichet, B.K. and Kobilka, B.K. (2012) Structure-Based Drug Screening for G-Protein-Coupled Receptors. Trends in Pharmacological Sciences, 33, 268-272. http://dx.doi.org/10.1016/j.tips.2012.03.007

[32] Hausch, F. (2013) Structures of Class B G Protein-Coupled Receptors: Prospects for Drug Discovery. Angewandte Chemie International Edition, 52, 12783-12785. http://dx.doi.org/10.1002/anie.201307542

[33] Hollenstein, K., Kean, J., Bortolato, A., Cheng, R.K.Y., Dore, A.S., Jazayeri, A., Cooke, R.M., Weir, M. and Marshall, F.H. (2013) Structure of Class B GPCR Corticotropin Releasing Factor Receptor 1. Nature, 499, 438-443. http://dx.doi.org/10.1038/nature12357

[34] Siu, F.Y., de Graaf, C., Han, G.W., Yang, D., Zhang, Z., Zhou, C., Xu, Q., Wacker, D., Joseph, J.S., Liu, W., Lau, J., Cherezov, V., Katritch, V., Wang, M.-W. and Stevens, R.C. (2013) Structure of the Human Glucagon Class B G-ProteinCoupled Receptor. Nature, 499, 444-451. http://dx.doi.org/10.1038/nature12393

[35] Siu, F.Y. and Stevens, R.C. (2010) RAMP-ing up Class B GPCR ECD Structural Coverage. Structure, 18, $1067-1068$. http://dx.doi.org/10.1016/j.str.2010.08.004

[36] Hollenstein, K., de Graaf, C., Bortolato, A., Wang, M.-W., Marshall, F.H. and Stevens, R.C. (2014) Insights into Structure of Class B GPCRs. Trends in Pharmacological Sciences, 35, 12-22. http://dx.doi.org/10.1016/j.tips.2013.11.001

[37] Bortolato, A., Dore, A.S., Hollenstein, K., Tehan, B.G., Mason, J.S. and Marshall, F.H. (2014) Structure of Class B GPCRS: New Horizons for Drug Discovery. British Journal of Pharmacology, 171, 3132-3145. http://dx.doi.org/10.1111/bph.12689

[38] Wootten, D., Lindmark, H., Kadmiel, M., Willcockson, H., Caron, K.M., Barwell, J., Drmota, T. and Poyner, D.R. (2013) Receptor Activity Modifying Proteins (RAMPS) Interact with the VPAC2 Receptor and CRF1 Receptors and Modulate Their Function. British Journal of Pharmacology, 168, 822-834. http://dx.doi.org/10.1111/j.1476-5381.2012.02202.x

[39] Archbold, J.K., Flanagan, J.U., Watkins, H.A., Gingell, J.J. and Hay, D.L. (2011) Structural Insights into RAMP Modification of Secretin Family G Protein-Coupled Receptors: Implications for Drug Development. Trends in Pharmacological Sciences, 32, 591-600. http://dx.doi.org/10.1016/j.tips.2011.05.007

[40] Christopoulos, A., Christopoulos, G., Morfis, M., Udawela, M., Laburthe, M., Couvineau, A., Kuwasako, K., Tilakaratne, N. and Sexton, P.M. (2003) Novel Receptor Partners and Function of Receptor Activity-Modifying Proteins. Journal of Biological Chemistry, 278, 3293-3297. http://dx.doi.org/10.1074/jbc.C200629200

[41] Roux, B.T. and Cottrell, G.S. (2014) G Protein-Coupled Receptors: What a Difference a "Partner” Makes. International Journal of Molecular Sciences, 15, 1112-1142. http://dx.doi.org/10.3390/ijms15011112 
[42] Foord, S.M. and Marshall, F.H. (1999) RAMPS: Accessory Proteins for Seven Transmembrane Domain Receptors. Trends in Pharmacological Sciences, 20, 184-187. http://dx.doi.org/10.1016/s0165-6147(99)01347-4

[43] Moore, E.L., Gingell, J.J., Kane, S.A., Hay, D.L. and Salvatore, C.A. (2010) Mapping the CGRP Receptor Ligand Binding Domain: Tryptophan-84 of RAMP1 Is Critical for Agonist and Antagonist Binding. Biochemical and Biophysical Research Communications, 394, 141-145. http://dx.doi.org/10.1016/j.bbrc.2010.02.131

[44] Schottelius, M. and Wester, H.-J. (2009) Molecular Imaging Targeting Peptide Receptors. Methods, 48, 161-177. http://dx.doi.org/10.1016/j.ymeth.2009.03.012

[45] Fani, M., Maecke, H.R. and Okarvi, S.M. (2012) Radiolabelled Peptides: Valuable Tools for the Detection and Treatment of Cancer. Theranostics, 2, 481-501. http://dx.doi.org/10.7150/thno.4024

[46] Beebe, X., Darzak, D., Rachel, A., Davis-Taber, R.A., Uchic, M.E., Scott, V.E., Jarvis, M.F. and Stewart, A.O. (2008) Discovery and SAR of Hydrazide Antagonists of the Pituitary Adenylate Cyclase-Activating Polypeptide (PACAP) Receptor Type 1 (PAC1-R). Bioorganic and Medicinal Chemical Letters, 18, 2162-2166. http://dx.doi.org/10.1016/j.bmcl.2008.01.052

[47] Chu, A., Caldwel, J.S. and Chen, Y.C. (2010) Identification and Characterization of a Small Molecule Antagonist of Human VPAC2 Receptor. Molecular Pharmacology, 77, 95-101. http://dx.doi.org/10.1124/mol.109.060137

[48] Neumann, J.M., Couvineau, A., Murail, S., Lacapère, J.J., Jamin, N. and Laburthe, M. (2008) Class-B GPCR Activation: Is Ligand Helix-Capping the Key? Trends in Biochemical Sciences, 33, 314-319. http://dx.doi.org/10.1016/j.tibs.2008.05.001

[49] Watkins, H.A., Au, M. and Hay, D.L. (2012) The Structure of Secretin Family GPCR Peptide Ligands: Implications for Receptor Pharmacology and Drug Development. Drug Discovery Today, 17, 1006-1014. http://dx.doi.org/10.1016/j.drudis.2012.05.005

[50] Lee, E.H. and Seo, S.R. (2014) Neuroprotective Roles of Pituitary Adenylate Cyclase-Activating Polypeptide in Neurodegenerative Diseases. BMB Reports, 47, 369-375. http://dx.doi.org/10.5483/BMBRep.2014.47.7.086

[51] Mayo, K.E., Miller, L.J., Bataille, D., Dalle, S., Göke, B., Thorens, B. and Drucker, D.J. (2003) International Union of Pharmacology: XXXV. The Glucagon Receptor Family. Pharmacological Reviews, 55, 165-194. http://dx.doi.org/10.1124/pr.55.1.6

[52] Will-Shahab, L., Wallukat, G. and Küttner, I. (1992) G Protein-Coupled PACAP Receptors in Cardiac Sarcolemmal Membranes. Journal of Molecular Cellular Cardiology, 24, S22. http://dx.doi.org/10.1016/0022-2828(92)91574-O

[53] Scaldaffieri, M.L., Modesti, A., Palumbo, C., Ulisse, S., Fabbri, A., Picione, E., Frajese, G. and Moretti, C. (2000) Pituitary Adenylate Cyclase Activating Polypeptide and PACAP-Receptor Type 1 Expression in Rat and Human Placenta. Endocrinology, 141, 1158-1167. http://dx.doi.org/10.1210/endo.141.3.7346 http://dx.doi.org/10.1210/en.141.3.1158

[54] Colwell, C.S., Michel, S., Itri, J., Rodriguez, W., Tam, J., Lelievre, V., Hu, Z. and Waschek, J.A. (2004) Selective Deficits in the Circadian Light Response in Mice Lacking PACAP. American Journal of Physiology, Regulatory, Integrative and Comparative Physiology, 287, 1194-1201. http://dx.doi.org/10.1152/ajpregu.00268.2004

[55] Pantazopoulos, H., Dolatshad, H. and Davis, F.C. (2010) Chronic Stimulation of the Hypothalamic Vasoactive Intestinal Peptide Receptor Lengthen Circadian Period in Mice and Hamsters. American Journal of Physiology, Regulatory, Integrative and Comparative Physiology, 299, R379-R385. http://dx.doi.org/10.1152/ajpregu.00176.2010

[56] Girard, B.A., Lelievre, V., Braas, K.M., Razinia, T., Vizzard, M.A., Ioffe, Y., El Meskini, R., Ronnett, G.V., Waschek, J.A. and May, V. (2006) Noncompensation in Peptide/Receptor Gene Expression and Distinct Behavioral Phenotypes in VIP and PACAP Deficient Mice. Journal of Neurochemistry, 99, 499-513. http://dx.doi.org/10.1111/j.1471-4159.2006.04112.x

[57] Jaworski, D.M. and Proctor, M.D. (2000) Developmental Regulation of Pituitary Adenylate Cyclase-Activating Polypeptide and PAC1 Receptor mRNA Expression in the Rat Central Nervous System. Developmental Brain Research, 120, 27-39. http://dx.doi.org/10.1016/S0165-3806(99)00192-3

[58] Sun, C., Song, D., Davis-Taber, R.A., Barrett, L.W., Scott, V.E., Richardson, P.L., Pereda-Lopez, A., Uchic, M.E., Solomon, L.R., Lake, M.R., Walter, K.A., Hajduk, P.J. and Olejniczak, E.T. (2007) Solution Structure and Mutational Analysis of Pituitary Adenylate Cyclase-Activating Polypeptide Binding to the Extracellular Domain of PAC1-Rs. Proceedings of the National Academy of Sciences, 104, 7875-7880. http://dx.doi.org/10.1073/pnas.0611397104

[59] Nicole, P., Lins, L., Rouyer-Fessard, C., Drouot, C., Fulcrand, P., Thomas, A., Couvineau, A., Martinez, J., Brasseur, R. and Laburthe, M. (2000) Identification of Key Residue for Interaction of Vasoactive Intestina Peptide with Human VPAC1 and VPAC2 Receptors and Development of Highly Selective VPAC1 Receptor Agonist. Journal of Biological Chemistry, 275, 24003-24012. http://dx.doi.org/10.1074/jbc.M002325200

[60] Igarashi, H., Ito, T., Pradhan, T.K., Mantey, S.A., Hou, W., Coy, D.H. and Jensen R.T. (2002) Elucidation of the Vasoactive Intestinal Peptide Pharmacophore for VPAC2 Receptors in Human and Rat Comparison to the Pharmacophore 
for VPAC1 Receptors. Journal of Pharmacology and Experimental Therapeutics, 303, 445-460. http://dx.doi.org/10.1124/jpet.102.038075

[61] Laburthe, M., Couvineau, A. and Marie, J.C. (2002) Molecular Pharmacology and Structure of VPAC Receptors for VIP and PACAP. Receptor Channels, 108, 137-153. http://dx.doi.org/10.1080/10606820213680

[62] Igarashi, H., Ito, T., Mantey, S.A., Pradhan, T.K., Hou, W., Coy, D.H. and Jensen, R.T. (2005) Development of Simplified Vasoactive Intestinal Peptide Analogs with Receptor Selectivity and Stability for Human Vasoactive Intestinal Peptide/Pituitary Adenylate Cyclase-Activating Polypeptide Receptors. Journal of Pharmacology and Experimental Therapeutics, 315, 370-381. http://dx.doi.org/10.1124/jpet.105.088823

[63] Dickson, L. and Finlayson, K. (2009) VPAC and PAC Receptors: From Ligands to Function. Pharmacology \& Therapeutics, 121, 294-316. http://dx.doi.org/10.1016/j.pharmthera.2008.11.006

[64] Yadav, M., Huang, M.-C. and Goetzl, E.J. (2011) VPAC1 (Vasoactive Intestinal Peptide (VIP) Receptor Type 1) G Protein Coupled Receptor Mediation of VIP Enhancement of Murine Experimental Colitis. Cellular Immunology, 267, 124-132. http://dx.doi.org/10.1016/j.cellimm.2011.01.001

[65] Ma, B.-Q., Zhang, M. and Ba, L. (2015) Plasma Pituitary Adenylate Cyclase-Activating Polypeptide Concentrations and Mortality after Acute Spontaneous Basal Ganglia Hemorrhage. Clinica Chimica Acta, 439, 102-106. http://dx.doi.org/10.1016/j.cca.2014.10.010

[66] Lin, C.-H., Chiu, L., Lee, H.-T., Chiang, C.-W., Liu, S.-P., Hsu, Y.-H., Lin, S.-Z., Hsu, C.-Y., Hsieh, C.-H. and Shyu, W.-C. (2015) PACAP38/PAC1 Signaling Induces Bone Marrow-Derived Cells Homing to Ischemic Brain. Stem Cells, 33, 1153-1172. http://dx.doi.org/10.1002/stem.1915

[67] Ressler, K.J., Mercer, K.B., Bradley, B., Jovanovic, T., Mahan, A., Kerley, K., Norrholm, S.D., Kilaru, V., Smith, A.K., Myers, A.J., Ramirez, M., Engel, A., Hammack, S.E., Toufexis, D., Braas, K.M., Binder, E.B. and May, V. (2011) Post-Traumatic Stress Disorder Is Associated with PACAP and PAC1 Receptor. Nature, 470, 492-497. http://dx.doi.org/10.1038/nature09856

[68] Igarashi, H., Fujimori, N., Ito, T., Nakamura, T., Oono, T., Nakamura, K., Suzuki, K., Jensen, R.T. and Takayanagi, R. (2011) Vasoactive Intestinal Peptide (VIP) Receptor-Elucidation of Structure and Function for Therapeutic Applications. International Journal of Clinical Medicine, 2, 500-508. http://dx.doi.org/10.4236/ijcm.2011.24084

[69] Baranowska, B., Radzikowska, M., Wasilewska-Dziubinska, E., Roguski, K. and Borowiec, M. (2000) Disturbed Release of Gastrointestinal Peptides in Anorexia Nervosa and Obesity. Diabetes, Obesity and Metabolism, 2, 99-103. http://dx.doi.org/10.1046/j.1463-1326.2000.00070.x

[70] Ohtaki, H., Nakamachi, T., Dogi, K., Aizawa, Y., Takaki, A., Hodoyama, K., Yofu, S., Hashimoto, H., Shintani, N., Baba, A., Kopf, M., Iwakura, M., Arimura, A. and Shioda, S. (2006) Pituitary Adenylate Cyclase-Activating Polypeptide (PACAP) Decreases Ischemic Neuronal Cell Death in Association with IL-6. Proceedings of the National Academy of Sciences, 103, 7488-7493. http://dx.doi.org/10.1073/pnas.0600375103

[71] O’Donnell, M., Garippa, R.J., Rinaldi, N., Selig, W.M., Simko, B., Renzetti, L., Tannu, S.A., Wassermann, M.A., Welton, A. and Bolin, D.R. (1994) Ro 25-1553: A Novel, Long-Acting Vasoactive Intestinal Peptide Agonist. Part I: In Vitro and in Vivo Bronchodilator Studies. Journal of Pharmacology and Experimental Therapeutics, 270, 1282-1288.

[72] O’Donnell, M., Garippa, R.J., Rinald, I.N., Selig, W.M., Tocker, J.E., Tannu, S.A., Wasserman, M.A., Welton, A. and Bolin, D.R. (1994) RO 25-1553: A Novel, Long-Acting Vasoactive Intestinal Peptide Agonist. Part II: Effect on in Vitro and in Vivo Models of Pulmonary Anaphylaxis. Journal of Pharmacology and Experimental Therapeutics, 270, 1289-1294.

[73] Leroux, P., Vaudry, H., Fournier, A., St-Pierre, S. and Pelletier, G. (1984) Characterization and Localization of Vasoactive Intestinal Peptide Receptors in the Rat Lung. Endocrinology, 114, 1506-1512. http://dx.doi.org/10.1210/endo-114-5-1506

[74] Polak, J.M. and Bloom, S.R. (1982) Occurrence and Distribution of Regulatory Peptides in the Respiratory Tract. Experimental Lung Research, 3, 313-328. http://dx.doi.org/10.3109/01902148209069660

[75] Hashimoto, H., Shintani, N., Nishino, A., Okabe, M., Ikawa, M., Matsuyama, S., Itoh, K., Yamamoto, K., Tomimoto, S., Fujit, A.T., Hagihara, N., Mori, W., Koyama, Y., Matsuda, T., Nagata, S. and Baba, A. (2000) Mice with Markedly Reduced PACAP (PAC1) Receptor Expression by Targeted Deletion of the Signal Peptide. Journal of Neurochemistry, 75, 1810-1817. http://dx.doi.org/10.1046/j.1471-4159.2000.0751810.x

[76] Zawilska, J.B., Dejda, A., Niewiadomski, P., Gozes, I. and Nowak, J.Z. (2005) Receptors for VIP and PACAP in Guinea Pig Cerebral Cortex. Effects on Cyclic AMP Synthesis and Characterization by 125I-VIP Binding. Journal of Molecular Neuroscience, 25, 215-224. http://dx.doi.org/10.1385/JMN:25:3:215

[77] Joo, K.M., Chung, Y.H., Kim, M.K., Nam, R.H., Lee, B.L. and Cha, C.I. (2004) Distribution of Vasoactive Intestinal Peptide and Pituitary Adenylate Cyclase-Activating Polypeptide Receptors (VPAC1, VPAC2, and PAC1 Receptor) in the Rat Brain. Journal of Comparative Neurology, 476, 388-413. http://dx.doi.org/10.1002/cne.20231 
[78] Cuha-Reis, D., Ribeiro, J.A. and Sebastiao, A.M. (2005) VIP Enhances Synaptic Transmission to Hippocampal CA1 Pyramidal Cells through Activation of both VPAC1 and VPAC2 Receptors. Brain Research, 1049, 52-60. http://dx.doi.org/10.1016/j.brainres.2005.04.077

[79] Blechman, J. and Levkowitz, G. (2013) Alternative Splicing of the Pituitary Adenylate Cyclase-Activating Polypeptide Receptor PAC1: Mechanism of Fine Tuning of Brain Activity. Frontiers in Endocrinology, 4, 1-19. http://dx.doi.org/10.3389/fendo.2013.00055

[80] Lang, B., Song, B., Davidson, W., MacKenzie, A., Smith, N., McCaig, C.D., Harmar, A.J. and Shen, S. (2006) Expression of the Human PAC1 Receptor Leads to Dose-Dependent Hydrocephalus-Related Abnormalities in Mice. Journal of Clinical Investigations, 116, 1924-1934. http://dx.doi.org/10.1172/JCI27597

[81] Sun, Q.-Q., Prince, D.A. and Huguenard, J.R. (2003) Vasoactive Intestinal Peptide and Pituitary Adenylate Cyclase Activating Polypeptide Activate Hyperpolarization Activated Cation Current and Depolarize Thalamocortical Neurons in Vitro. Journal of Neuroscience, 23, 2751-2758.

[82] Hoshino, M., Yanihara, C., Hong, Y.-M., Kishida, S., Katsumaru, Y., Vandermeers, A., Vandermeers-Piret, M.-C., Robberecht, P., Christophe, J. and Yanaihara, N. (1984) Primary Structure of Helodermin, a VIP-Secretin-Like Peptide Isolated from Gila Monster Venom. FEBS Letters, 178, 233-239. http://dx.doi.org/10.1016/0014-5793(84)80607-9

[83] Robberecht, P., Waelbroeck, M., Camus, J.C., DeNeef, P., Coy, D.H. and Christophe, J. (1984) Effect of His1 Modifications on the Ability of Vasoactive Intestinal Peptide to Stimulate Adenylate Cyclase from Rat and Human Tissue. Peptides, 5, 529-535. http://dx.doi.org/10.1016/0196-9781(84)90110-4

[84] Laburthe, M., Couvineau, A. and Tan, V. (2007) Class II G Protein-Coupled Receptors for VIP and PACAP Structure, Models of Activation and Pharmacology. Peptides, 28, 1631-1639. http://dx.doi.org/10.1016/j.peptides.2007.04.026

[85] Hoare, S.R.J. (2005) Mechanisms of Peptide and Nonpeptide Ligand Binding to Class B G-Protein Coupled Receptors. Drug Discovery Today, 10, 417-427. http://dx.doi.org/10.1016/S1359-6446(05)03370-2

[86] Dong, M., Pinon, D.I., Asmann, Y.W. and Miller, L.J. (2006) Possible Endogenous Agonist Mechanism for Activation of Secretin Family G-Protein-Coupled Receptors. Molecular Pharmacology, 70, 206-213. http://dx.doi.org/10.1124/mol.105.021840

[87] terHaar, E., Koth, C.M., Abdul-Manan, N., Swenson, L., Coll, J.T., Lippke, J.A., Lepre, C.A., Garcia-Guzman, M. and Moore, J.M. (2010) Crystal Structure of the Ectodomain Complex of the CGRP Receptor, a Class B GPCR, Reveals the Site of Drug Antagonism. Structure, 18, 1083-1093. http://dx.doi.org/10.1016/j.str.2010.05.014

[88] Parthier, C., Reedtz-Runge, S., Rudolph, R. and Stubbs, M.T. (2009) Passing the Baton in Class B GPCRs: Peptide Hormone Activation via Helix Induction. Trends in Biochemical Sciences, 34, 303-310. http://dx.doi.org/10.1016/j.tibs.2009.02.004

[89] Usdin, T.B., Bonner, T.I. and Mezey, E. (1994) Two Receptors for Vasoactive Intestinal Polypeptide with Similar Specificity and Complementary Distributions. Endocrinology, 135, 2662-2680. http://dx.doi.org/10.1210/endo.135.6.7988457

[90] Harikrishnan, L.S., Srivastava, N., Kayser, L.E., Nirschl, D.S., Kumaragurubaran, K., Roy, A., Gupta, A., Karmakar, S., Karatt, T., Mathur, A., Burford, N.T., Chen, J., Kong, Y., Cvijic, M.E., Coope, C.B., Poss, M.A., Trainor, G.L. and Wong, T.W. (2012) Identification and Optimization of Small Molecule Antagonists of Vasoactive Intestinal Peptide Receptor-1 (VIPR1). Bioorganic and Medicinal Chemistry Letters, 22, 2287-2290. http://dx.doi.org/10.1016/j.bmcl.2012.01.082

[91] Dockray, G.J. (1994) Vasoactive Intestinal Polypeptide and Related Peptides. In: Walsh, J.H. and Dockray, G.J., Eds., Gut Peptides, Raven Press Ltd., New York, 447-472.

[92] Inagaki, N., Yoshida, H., Mizuta, M., Fujii, Y., Gonol, T., Mijazaki, J. and Seino, S. (1994) Cloning and Functional Characterization of a Third Pituitary Adenylate Cyclase Activating Polypeptide Receptor Subtype Expressed in Insulin Secreting Cells. Proceedings of the National Academy of Sciences, 91, 2679-2683. http://dx.doi.org/10.1073/pnas.91.7.2679

[93] Sekiguchi, Y., Kasai, K., Hasegawa, K., Suzuki, Y. and Shimoda, S. (1994) Glycogenolytic Activity of Pituitary Adenylate Cyclase Activating Polypeptide (PACAP) in Vivo and in Vitro. Life Science, 55, 1219-1228. http://dx.doi.org/10.1016/0024-3205(94)00661-X

[94] Yokota, C., Kawai, K., Ohashi, S., Watanabe, Y. and Yamashita, K. (1995) PACAP Stimulates Glucose Output from the Perfused Rat liver. Peptides, 16, 55-60. http://dx.doi.org/10.1016/0196-9781(94)00143-T

[95] Wei, Y. and Mojsov, S. (1996) Multiple Human Receptors for Pituitary Adenylate Cyclase Activating Polypeptide and Vasoactive Intestinal Peptide Are Expressed in Tissue-Specific Manner. Annals of the New York Academy of Sciences, 805, 624-627. http://dx.doi.org/10.1111/j.1749-6632.1996.tb17531.x

[96] Yu, R.J., Zhang, H.H., Huang, L., Liu, X.F. and Chen, J.S. (2011) Anti-Hyperglycemic, Antioxidant and Anti-Inflammatory Effects of VIP and a VPAC1 Agonist on Streptozotocin-Induced Diabetic Mice. Peptides, 32, $216-222$. 
http://dx.doi.org/10.1016/j.peptides.2010.11.017

[97] Ago, Y., Condro, M.C., Tan, Y.-V., Ghiani, C.A., Colwell, C.S., Cushman, J.D., Fanselow, M.S., Hashimoto, H. and Waschek, J.A. (2015) Reductions in Synaptic Proteins and Selective Alteration of Prepulse Inhibition in Male C57BL/6 Mice after Postnatal Administration of a VIP Receptor (VIPR2) Agonist. Psychopharmacology, 232, 21812189. http://dx.doi.org/10.1007/s00213-014-3848-z

[98] Asnicar, M.A., Köster, A., Heiman, M.L., Tinsley, F., Smith, D.P., Galbreath, E., Fox, N., Ma, Y.L. and Blum, W.F. (2002) Vasoactive Intestinal Polypeptide/Pituitary Adenylate Cyclase-Activating Peptide Receptor 2 Deficiency in Mice Results in Growth Retardation and Increased Basal Metabolic Rate. Endocrinology, 143, 3994-4006. http://dx.doi.org/10.1210/en.2002-220354

[99] Nicot, A., Otto, T., Brabet, P. and DiCicco-Bloom, M. (2004) Altered Social Behavior in Pituitary Adenylate CyclaseActivating Type 1 Receptor-Deficient Mice. Journal of Neuroscience, 24, 8786-8795. http://dx.doi.org/10.1523/JNEUROSCI.1910-04.2004

[100] Otto, C., Martin, M., Wolfer, D.P., Lipp, H.-P., Maldonado, R. and Schütz, G. (2001) Altered Emotional Behavior in PACAP-Type-I-Receptor-Deficient Mice. Molecular Brain Research, 92, 78-84. http://dx.doi.org/10.1016/S0169-328X(01)00153-X

[101] Moreno, D., Gourlet, P., De Neef, P., Cnudde, J., Waelbroeck, M. and Robberecht, P. (2000) Development of Selective Agonists and Antagonists for the Human Vasoactive Intestinal Polypeptide VPAC 2 Receptor. Peptides, 21, $1543-1549$. http://dx.doi.org/10.1016/S0196-9781(00)00309-0

[102] Gourlet, P., Vertongen, P., Vandermeers, A., Vandermeers-Piret, M.-C., Rathe, J., de Neef, P., Waelbroeck, M. and Robberecht P. (1997) The Long-Acting Vasoactive Intestinal Polypeptide Agonist Ro 25-1553 Is Highly Selective of the VIP2 Receptor Subclass. Peptides, 18, 403-408. http://dx.doi.org/10.1016/S0196-9781(96)00322-1

[103] Ceraudo, E., Tan, Y.-V., Nicole, P., Couvineau, A. and Laburthe, M. (2008) The N-Terminal Parts of VIP and Antagonist PG97-269 Physically Interact with Different Regions of the Human VPAC1 Receptor. Journal of Molecular Neurosciences, 36, 245-248. http://dx.doi.org/10.1007/s12031-008-9073-7

[104] Boni, L.J., Ploug, K.B., Jansen-Olensen, J. and Gupta, S. (2009) The in Vivo Effect of VIP, PACAP-38 and PACAP-27 and mRNA Expression of Their Receptors in Rat Middle Meningeal Artery. Cephalagia, 29, 837-847. http://dx.doi.org/10.1111/j.1468-2982.2008.01807.x

[105] Dickson, L., Aramori, I., McCulloch, J., Sharkey, J. and Finlayson, K. (2006) A Systematic Comparison of Intracellular Cyclic AMP and Calcium Signaling Highlights Complexities in Human VPAC/PAC Receptor Pharmacology. Neuropharmacology, 51, 1086-1098. http://dx.doi.org/10.1016/j.neuropharm.2006.07.017

[106] Pan, C.Q., Li, F., Tom, I., Wang, W., Dumas, M., Froland, W., Yung, S.L., Li, Y., Roczniak, S., Claus, T.H., Wang, C.Y. and Whelan, J.P. (2007) Engineering Novel VPAC2-Selective Agonists with Improved Stability and GlucoseLowering Activity in Vivo. Journal of Pharmacology and Experimental Therapeutics, 320, 900-906. http://dx.doi.org/10.1124/jpet.106.112276

[107] Xia, M., Sreedharan, S.P., Bolin, D.R., Gaufo, G.O. and Goetzl, E.J. (1997) Novel Cyclic Peptide Agonist of High Potency and Selectivity for the Type II Vasoactive Intestinal Peptide Receptor. Journal of Pharmacology and Experimental Therapeutics, 281, 629-633.

[108] Vertongen, P., Schiffmann, S.N., Gourlet, P. and Robberecht, P. (1997) Autoradiographic Visualization of the Receptor Subclasses for Vasoactive Intestinal Polypeptide. Peptides, 18, 1547-1554. http://dx.doi.org/10.1016/S0196-9781(97)00229-5

[109] Uchida, D., Tatsuno, I., Tanaka, T., Hirai, A., Saito, Y., Moro, O. and Tajima, M. (1998) Maxadilan Is a Specific Agonist and Its Deleted Peptide (M65) Is a Specific Antagonist for PACAP Type 1 Receptor. Annals of the New York Academy of Sciences, 865, 253-258. http://dx.doi.org/10.1111/j.1749-6632.1998.tb11185.x

[110] Lerner, E.A., Iuga, A.O. and Reddy, V.B. (2007) Maxadilan, a PAC1 Agonist from Sand Flies. Peptides, 28, 16511654. http://dx.doi.org/10.1016/j.peptides.2007.06.021

[111] Lerner, E.A. and Shoemaker, C.B. (1992) Maxadilan: Cloning and Functional Expression of the Gene Encoding This Potent Vasodilator Peptide. Journal of Biological Chemistry, 267, 1062-1066.

[112] Hadwen, J., MacKenzie, D., Shamim, F., Mongeon, K., Holcik, M., MacKenzie, A. and Faroq, F. (2014) VPAC2 Receptor Agonist BAY 55-9837 Increases SMN Protein Levels and Moderates Disease Phenotype in Severe Spinal Muscular Atrophy Mouse Models. Orphanet Journal of Rare Diseases, 9, 4. http://www.ojrd.com/content/9/1/4

[113] Sugarman, E.A., Nagan, N., Zhu, H., Akmaev, V.R., Zhou, Z., Rohlfs, E.M., Flynn, K., Hendrickson, B.C., Scholl, T., Sirko-Osada, D.A. and Allitto, B.A. (2012) Pan-Ethnic Carrier Screening and Prenatal Diagnosis for Spinal Muscular Atrophy: Clinical Laboratory Analysis of $>72400$ Specimens. European Journal of Genetics, 20, 27-32. http://dx.doi.org/10.1038/ejhg.2011.134

[114] Lindén, A., Hansson, L., Andersson, A., Palmqvist, M., Arvidsson, P., Löfdahl, C.-G. and Larsson, P. (2003) Broncho- 
dilation by an Inhaled VPAC2 Receptor Agonist in Patients with Stable Asthma. Thorax, 58, 217-221. http://dx.doi.org/10.1136/thorax.58.3.217

[115] Moro, O. and Lerner, E.A. (1997) Maxadilan, the Vasodilator from Sand Flies, Is a Specific Pituitary Adenylate Cyclase Activating Peptide Type I Receptor Agonist. Journal of Biological Chemistry, 272, 966-970. http://dx.doi.org/10.1074/jbc.272.2.966

[116] Svensjö, E., Saraiva, E.M., Bozza, M.T., Oliveira, S.M.P., Lerner, E.A. and Scharfstein, J. (2009) Salivary Gland Homogenates of Lutzomyia longipalpis and Its Vasodilatory Peptide Maxadilan Cause Plasma Leakage via PAC1 Receptor Activation. Journal of Vascular Research, 46, 435-446. http://dx.doi.org/10.1159/000197866

[117] Hoare, S.R.J. (2007) Allosteric Modulators of Class B G Protein-Coupled Receptors. Current Neuropharmacology, 5, 168-179. http://dx.doi.org/10.2174/157015907781695928

[118] Pissarek, M. (2014) Neuropeptide Receptors in Pain Circuitries: Useful Targets for CNS Imaging with Non-Peptide Ligands Suitable for PET? World Journal of Neuroscience, 4, 353-383. http://dx.doi.org/10.4236/wjns.2014.44040

[119] Dong, M., Pinon, D.I. and Miller, L.J. (2008) Exploration of the Endogenous Agonist Mechanism for Activation of Secretin and VPAC1 Receptors Using Synthetic Glycosylated Peptides. Journal of Molecular Neuroscience, 36, 254259. http://dx.doi.org/10.1007/s12031-008-9058-6

[120] Robl, J.A. (1990) A New and Versatile Route for the Synthesis of Highly Substituted Benzenoids. Tetrahedron Letters, 31, 3421-3424. http://dx.doi.org/10.1016/S0040-4039(00)97412-4

[121] Madsen, P., Ling, A., Plewe, M., Sams, C.K., Knudsen, L.B., Sidelmann, U.G., Ynddal, L., Brand, C.L., Andersen, B., Murphy, D., Teng, M., Truesdale, L., Kiel, D., May, J., Kuki, A., Shi, S.H., Johnson, M.D., Teston, K., Feng, J., Lakis, J., Anderes, K., Gregor, V. and Lau, J. (2002) Optimization of Alkylidene Hydrazide Based Human Glucagon Receptor Antagonists. Discovery of the Highly Potent and Orally Available 3-Cyano-4-Hydroxybenzoic Acid [1-(2,3,5,6teramethylbenzyl)-1H-indol-4-ylmethylene] Hydrazide. Journal of Medicinal Chemistry, 45, 5755-5775. http://dx.doi.org/10.1021/jm0208572

[122] Yu, R., Guo, X., Zhong, J., Li, M., Zeng, Z. and Zhang, H. (2012) The N-Terminal HSDCIF Is Required for Cell Surface Trafficking and Dimerization of Family B G Protein Coupled Receptor PAC1. PLoS ONE, 7, e51811.

[123] Jagoda, E.M., Lang, L., McCullough, K., Contoreggi, C., Moon, K.B., Ma, Y., Rice, K.C., Szajek, L.P., Eckelman, W.C. and Kiesewetter, D.O. (2011) [76Br]BMK-152, a Nonpeptide Analogue, with High Affinity and Low Nonspecific Binding for the Corticotrophin-Releasing Factor Type 1 Receptor. Synapse, 65, 910-918. http://dx.doi.org/10.1002/syn.20919

[124] Zuev, D., Mattson, R.J., Huang, H., Mattson, G.K., Zueva, L., Nielsen, M., Kozlowski, E.S., Huang, X.S., Dedong, W., Gao, Q., Lodge, N.J., Bronson, J.J. and Macor, J.E. (2011) Potential CRF1R PET Imaging Agents: N-Flu-oroalkyl8-(6-methoxy-2-methyl-pyridin-3-yl)-2,7-dime-thyl-N-alkylpyrazolo[1,5-a][1,3,5]triazin-4-amines. Bioorganic \& Medicinal Chemistry Letters, 21, 2484-2488. http://dx.doi.org/10.1016/j.bmcl.2011.02.050

[125] Chugunov, A.O., Simms, J., Poyner, D.R., Dehouck, Y., Rooman, M., Gilis, D. and Langer, I. (2010) Evidence That Interaction between Conserved Residues in Transmembrane Helices 2,3 and 7 Are Crucial for Human VPAC 1 Receptor Activation. Molecular Pharmacology, 78, 394-401. http://dx.doi.org/10.1124/mol.110.063578

[126] Langer, I. (2012) Conformational Switches in the VPAC1 Receptor. British Journal of Pharmacology, 166, 79-84. http://dx.doi.org/10.1111/j.1476-5381.2011.01616.x

[127] Dong, M., Xu, X., Ball, A.M., Makhoul, J.A., Lam, P.C.H., Pinon, D.I., Orry, A., Sexton, P.M., Abagyan, R. and Miller, L.J. (2012) Mapping Spatial Approximations between the Amino Terminus of Secretin and Each of the Extracellular Loops of Its Receptor Using Cysteine Trapping. FASEB Journal, 26, 5092-5105. http://dx.doi.org/10.1096/fj.12-212399

[128] Katritch, V., Cherezov, V. and Stevens, R.C. (2012) Diversity and Modularity of G Protein-Coupled Receptor Structures. Trends in Pharmacological Sciences, 33, 17-26. http://dx.doi.org/10.1016/j.tips.2011.09.003

[129] Unal, H. and Karnik, S.S. (2012) Domain Coupling in GPCRs: The Engine for Induced Conformational Changes. Trends in Pharmacological Sciences, 33, 79-88. http://dx.doi.org/10.1016/j.tips.2011.09.007

[130] Avlani, V.A., Gregory, K.J., Morton, C.J., Parker, M.W., Sexton, P.M. and Christopoulos, A. (2007) Critical Role for the Second Extracellular Loop in the Binding of Both Orthosteric and Allosteric G Protein-Coupled Receptor Ligands. Journal of Biological Chemistry, 282, 25677-25686. http://dx.doi.org/10.1074/jbc.M702311200

[131] Solano, R.M., Langer, I., Perret, J., Vertongen, P., Juarranz, M.G., Robberecht, P. and Waelbroeck, M. (2001) Two Basic Residues of the H-VPAC1 Receptor Second Transmembrane Helix Are Essential for Ligand Binding and Signal Transduction. Journal of Biological Chemistry, 276, 1084-1088. http://dx.doi.org/10.1074/jbc.M007686200

[132] Donelly, D. (2012) The Structure and Function of the Glucagon-Like Peptide-1 Receptor and Its Ligands. British Journal of Pharmacology, 166, 27-41. http://dx.doi.org/10.1111/j.1476-5381.2011.01687.x

[133] Lagerström, M.C. and Schiöth, H.B. (2008) Structural Diversity of G Protein-Coupled Receptors and Significance for 
Drug Discovery. Nature Reviews, 7, 339-357. http://dx.doi.org/10.1038/nrd2518 http://dx.doi.org/10.1038/nrd2592

[134] Mustafa, T. and Eiden, L.E. (2006) Secretin Superfamily: PACAP, VIP and Related Neuropeptides In: Lajtha, A. and Lim, R., Eds., Handbook of Neurochemistry and Neurobiology: Neuroactive Proteins and Peptides, 3rd Edition, Springer-Verlag, Berlin, 476.

\section{Abbreviations}

a.a.r.: amino acid residue;

ADNF: activity-dependent neurotrophic factor;

AM: adrenomedullin;

AMY: amylin;

CLR: calcitonin receptor-like receptor;

CT: calcitonin;

CGRP: calcitonin-gene-related peptide;

CRF: corticotrophin releasing factor,

GLP: glucagon-like peptide;

GPCR: guanine-nucleotide-regulatory-protein-coupled receptor;

MAP kinase: mitogen-activated protein kinase;

MIP: macrophage inflammatory protein;

N-ted: N-terminal ectodomain;

PACAP: pituitary adenylate cyclase activating polypeptide;

PAC receptor: pituitary adenylate cyclase activating polypeptide receptor;

PET: positron emission tomography;

PHI: peptide-histidine-isoleucine;

PHM: peptide-histidine-methionin;

PTH: parathyroid hormone;

RAMP: receptor activity modifying protein;

RANTES: CC chemokine Regulated upon Activation, Normal T cell Expressed and Secreted;

MIP: macrophage inflammatory protein;

SAR: structure-activity relationships;

SPECT: single photon emission tomography;

7TMD: seven transmembrane domains;

VIP: vasoactive intestinal peptide;

cVIP: chicken VIP;

gpVIP: guinea pig VIP;

mVIP: mammalian VIP;

VPAC receptor: vasoactive intestinal peptide/pituitary adenylate cyclase activating polypeptide receptor. 